\title{
The influence of sediment cohesiveness on bioturbation effects due to Hydrobia ulvae on the initial erosion of intertidal sediments: A study combining flume and model approaches
}

\author{
Francis Orvain $^{\mathrm{a}, \mathrm{b},{ }^{*}, \text { Pierre-Guy Sauriau }}{ }^{\mathrm{a}}$, Cédric Bacher $^{\mathrm{a}}$ and Michel Prineau ${ }^{\mathrm{a}}$
}

\begin{abstract}
${ }^{a}$ CREMA (CNRS-IFREMER, UMR 10), Centre de Recherche en Ecologie Marine et Aquaculture de I'Houmeau, Place du Séminaire, BP 5, 17137, L'Houmeau, France

${ }^{b}$ Laboratoire de Biologie et de Biotechnologie Marine, Unité Mixte de Recherche Université et IFREMER Ecologie et Ecophysiologie des Mollusques, Université de Caen Basse-Normandie, 14032 Caen cedex, France
\end{abstract}

*: Corresponding author : F. Orvain, email address : F.Orvain@iutcaen.unicaen.fr

\begin{abstract}
:
Laboratory experiments performed in a recirculating flume were designed to quantify the bioturbation influence of the mud snail Hydrobia ulvae, one of the most abundant deposit feeders on European intertidal mudflats. Variations in sediment moisture content that occur between bedforms in shorenormal, ridge and runnel systems of intertidal mudflats were added to the model definition. Sediment erosion thresholds, erosion rates and the microalgal pigment composition of resuspended material were quantified for different $\mathrm{H}$. ulvae densities $(0,1000,5000,10000$ and 50000 snails m-2) and applied bed shear stresses. Two different sediment moisture contents were tested. In the absence of macrofauna, recorded turbidities increased up to the maximum applied value of $1.6 \mathrm{~Pa}$ and the addition of snails increased the resuspended mass at all bed shear stresses tested. The amount of resuspended mass depended on snail density; the amount of resuspended material was highest in sediment test beds that had the highest moisture contents (ridge-type sediments) and snail density. Resuspended and bioturbated sediment was characterised by an enrichment in phaeopigments compared to the underlying sediment. A nine-parameter model, which included sediment moisture content as a new variable, gave a reasonably good estimate of the resuspension of ridge- and runneltype sediments for the range of snail densities. An eight-parameter version of the model was adequate for quantifying erosion rates on intertidal mudflats not characterised by a ridge/runnel geomorphology.
\end{abstract}

Keywords: Resuspension; Bioturbation; Hydrobia ulvae; Sediment; Mudflat; Ridges and runnels; Chloropigments; Flume; Model 


\section{Introduction}

Quantifying the load of suspended matter at the spatial scale of intertidal mudflats requires an accurate description of the sediment transport processes based on the hydrodynamic regime, the physical properties of the sediment and the influence of benthic organisms living at the sediment-water interface. Although empirical equations for erosion have been well-established (Ariathurai and Krone, 1976; Mehta et al., 1982; Sheng and Villaret, 1989), and allow reliable predictions of erosion in hydraulic engineering (Mehta et al., 1989), experimental studies are needed to quantify the interactions between various physical factors (Amos et al., 1998; Dyer et al., 2000) and biological factors on intertidal mudflat sediment dynamics. For example, the sediment stability on mudflats may be affected by the presence of a stabilising biofilm made up of benthic diatoms and their associated exopolymer matrix (Grant et al., 1986; Paterson, 1989; Delgado et al., 1991; Underwood and Paterson, 1993; Yallop et al., 2000) and the presence of stabilising bacteria (Dade et al., 1996). Sediment transport may be influenced by the bioturbation activities of meiobenthos, macrobenthos and vertebrates (Nowell et al., 1981) and even the physical presence of these organisms at the sediment surface lead to more complex interactions (Rhoads and Young, 1970; Mc Call and Tevesz, 1982; Anderson, 1983).

Numerous studies have described the effects of bioturbation on cohesive sediment properties (e.g. Rhoads and Young, 1970, Eckman et al., 1981; Jumars et al., 1981; Nowell and Jumars, 1984), however, quantitative descriptions remain scarce (e.g. Davis, 1993; Willows et al., 1998, Andersen, 2001, Orvain et al., 2003) and the impact of a single species may involve modifications of several bulk sediment properties (Jumars and Nowell, 1984). For example, the population of the amphipod Corophium volutator exerts a stabilising influence on sediment-erosion rates (Grant and Daborn, 1994), but this species can reduce 
(Gerdol and Hughes, 1994) or enhance (Meadows and Tait, 1989) sediment erosion thresholds seasonally. Nevertheless, general trends can be described for the effects of macrofauna communities on sediment erosion (e.g Anderson, 1983; Swift, 1993; Widdows et al., 2000). Even though bioturbation activities of deposit-feeders may stabilise the sedimentwater interface, no studies are known to describe such a direct effect on muddy sediments. Intensive reworking of the top few centimetres of mud by deposit feeders produces a pelleted mucus- and biodeposit- rich surface layer that is easily resuspended by low velocity tidal currents (Rhoads and Young, 1970; Willows et al., 1998, Orvain et al., 2003). In contrast, some types of suspension-feeders may stabilise parts of the sediment-water interface through clump formation and biodeposit accumulation (see Ehrhold et al., 1998; Meadows et al., 1998; Widdows et al., 1998a; Widdows et al., 1998b).

There exist a few mathematical models of sediment erosion that include, explicitly, biologically-mediated processes (Willows et al., 1998; Orvain et al., 2003, Orvain, 2004). The model proposed by Willows et al. (1998) was based on experiments quantifying muddy sediment resuspension using the density of the bivalve Macoma balthica as a single controlling factor. They extropolated their findings to the Skeffling mudflats (Humber estuary, UK), where M. balthica is the dominant organism (Davey and Partridge, 1998). However, their model did not include variations in sediment properties. Many mudflats, such as those along the Marennes-Oléron Bay (France) which is also the site for the present study, have a ridge-runnel type geomorphology (Whitehouse et al., 2000) characterised in part by vertical profiles of moisture contents (Gouleau et al., 2000). Thus, one goals of our study was to modify and test the inclusion of sediment moisture content as an explicit variable in the Willows model.

Our main objectives were to determine if the Willows model describes well the influence on sediment erosion rates of another common bioturbator found on mudflats, 
Hydrobia ulvae, and then to predict the relative influence of the gastropod Hydrobia ulvae (a surface deposit-feeder) and $M$. balthica (a subsurface deposit-feeder and a facultative suspension feeder) on the erosion rates of cohesive sediments. H. ulvae is the dominant species in the intertidal areas of Marennes-Oléron Bay (Sauriau et al., 1989) and is observed on both the ridges and in runnels of the mudflat. Data from laboratory flume experiments were used to quantify the influence of the population density of $H$. ulvae on the resuspension of particulate matter and microalgal pigment concentrations from sediment beds with different moisture contents. This dataset was then used to test and evaluate two different versions of the Willows model.

\section{Methods}

\section{Study site}

The intertidal mudflats of the Marennes-Oléron Bay are located on the eastern and western coasts of a north-south oriented channel, which begins in the south of the Ile d'Oléron and widens in the north to constitute a large bay between the Ile d'Oléron and the mainland. On the eastern side, the intertidal areas are $20 \mathrm{~km}$ long and $4.5 \mathrm{~km}$ wide between the Seudre River and the Charente River. At Brouage, the midtide level parts of the mudflats are covered by a system of shore-normal ridges and runnels (Germaneau and Sauriau, 1996) (Fig. 1a). The gastropod Hydrobia ulvae is the principal deposit-feeder organism on these mudflats (Sauriau et al., 1989); population densities can reach up to 20,000 ind. ${ }^{-2}$ seasonally Sediment concentration profiles from cores collected on ridges and in runnels are significantly different (Gouleau et al., 2000): homogenous profiles of more compact mud are observed on ridges (wet bulk density between 400-800 kg.m ${ }^{-3}$ ) and a wider range of sediment concentrations in runnels. For example, in runnels there is a fluid mud gradient from the surface sediments (wet 
bulk density ca. 200-300 kg.m ${ }^{-3}$ ) down to approximately $2 \mathrm{~cm}$ depth, below which the sediment concentrations are higher and more similar to those measured on the ridge tops (Fig. $1 \mathrm{~b}$ and Fig. 1c). A complete description of the sedimentology at the study site is in Gouleau et al. (2000).

\section{Experimental design}

The experiments used a two-way factorial design with replication, in which "snail density" and "bedform” were fixed factors. Five snail densities and 2 sediment concentrations (representing ridges or runnels) were tested, for a total of 20 experiments (including one replicate per condition, $n=2$ ). Analyses of variance were calculated with Minitab software.

\section{Preparation of sediments for flume experiments}

Two large volumes of mud were collected from ridges and runnels on the Brouage mudflats. The sediments were brought back to the laboratory and each batch processed separately to create two large volumes of homogenized sediments representative of each bedform. All sediments were first sieved $(<1 \mathrm{~mm})$ to remove any macrofauna. The meiofauna were not removed.

To recreate runnel-type sediments, eleven (10 experiment beds and 1 control) experimental test beds were filled with the sieved and homogenised sediments collected from runnels. Each sediment test bed was $90 \mathrm{~cm}$ long, $40 \mathrm{~cm}$ wide and $20 \mathrm{~cm}$ high. The sediments were then allowed to consolidate and equilibrate submerged in seawater for 3 months until the depth profile of sediment moisture content was similar to that observed in field cores (Fig. 1c). The change in sediment moisture content ( $g$ water $/ g$ dry sediment $\times 100$ ) during the equilibration period was determined by measuring the moisture content profile in the control 
test bed every week (data not shown). Moisture content was measured from six cores $(3 \mathrm{~cm}$ in diameter) were sliced at millimetre intervals

To recreate ridge sediments, 10 experimental test beds were filled with the prepared sediments collected from ridges and placed immediately into the flume. The mud mixture was prepared such that sediment concentration depth profiles would be similar to those measured from ridges at the study site (Fig. 1b). Depth profiles of sediment concentration were measured in small control beds ( 1 for each experiment), which were prepared on the same time. Sediment moisture content depth profiles were measured on 3 non-frozen cores of the control bed sliced at millimetre intervals and processed as described above.

\section{Erosion experiments}

Sediment erosion was measured using the benthic flume HYDROBIOS ("HYDROdynamic and BIOlogical Synergy" installed at the Centre de Recherche sur les Ecosystèmes Marins et Aquacole, L'Houmeau, France; see Orvain et al., 2003 for a detailed description). In the flume, bed shear stress is generated by currents created with two turbines installed into the return pipe of the lower half of the flume.

The flow properties of the flume have been characterised by measuring current velocity profiles (Orvain et al., 2003). The infinite velocity $\left(u_{\infty}\right.$ in $\mathrm{m}^{-1} \mathrm{~s}^{-1}$ ) was determined and converted to bed shear stress using a calibration based on current profile analyses over a smooth mud bed . The relationship between $u^{*}, u_{\infty}$ and control frequency (denoted $F_{r}$ ) has been established from velocity profiles. The validity of the bed shear stress values and of the relationship between $u^{*}$ and $u_{\infty}$ was verified by measuring 8 velocity current profiles with an ultrasonic velocity meter (Minilab system) on a bed covered by thin tracks produced by snails. The following relationships were obtained:

$$
u^{*}=5.725 \times 10^{-4} \times F_{r}\left(r^{2}=0.97\right) \quad \text { and } \quad u^{*}=5.725 \times 10^{-2} \times u_{\infty}\left(r^{2}=0.96\right)
$$


Bed shear stress $\left(\tau_{f}\right)$ was calculated from the friction velocity according to: $\tau_{f}(P a)=\rho \times u *^{2}$, where $\rho=$ water density (1020 $\mathrm{kg} \mathrm{m}^{-3}$ for the sea water used in our experiments). The maximum bed shear stress on a test section was 1.6 Pa for the highest control frequency.

A filled experimental test bed was placed into the flume test section. The flume was then filled with $10 \mu \mathrm{m}$ filtered water (salinity adjusted to between 30-31\%o) until a thin water layer (5 mm) appeared on the sediment surface. Mud snails were added to the test section and small walls prevented the snails from escaping into the rest of the flume. After $5 \mathrm{~h}$ of simulated low-tide with the snails bioturbating the surface, the flume was filled until the water column height reached $0.15 \mathrm{~m}$ over the test bed. The animals dispersed very rapidly and randomly during the filling, and no animals remained on the test section after filling was completed. Therefore, we have assumed that the bed shear stress values calibrated on a smooth mud bed were valid.

Next, 14 stepwise increases of current velocity (from 0 to $0.60 \mathrm{~m} . \mathrm{s}^{-1}$ ), and each lasting 20 minutes, were applied to the test bed. The concentration of suspended particular matter (SPM in g. $l^{-1}$ ) and the pigment concentration (in $\mu$ g..$^{-1}$ ) in the flume were monitored at $15 \mathrm{~s}$ intervals using a multiparameter probe (MARTEC) suspended in the water column downstream of the test section. Quantitative changes in mineral and organic fractions of the SPM in the water column (5l subsamples) at the end of each current velocity interval. No bed erosion was observed in any of the experiments.

\section{Sediment and water sample analyses}

At the end of each "ridge" and "runnel" resuspension experiment, the sediment concentration in the top centimetre was estimated ( 3 cores per tank, $3 \mathrm{~cm}$ in diameter each). The sediment concentration (dry bulk density in $\mathrm{kg} . \mathrm{m}^{-3}$ ) was calculated from the moisture content using the following formula: 


$$
\gamma_{d}\left(k g \cdot m^{-3}\right)=\frac{\gamma_{s}}{w / 100 \cdot \gamma_{s}+1000}
$$

where $\gamma_{\mathrm{s}}$ is the assumed grain density $=2650 \mathrm{~kg} \cdot \mathrm{m}^{-3}$ and $w$ the moisture content (g water/ g dry sediment $\times 100$ ). The moisture content was determined after measured by drying the core sections at $60^{\circ} \mathrm{C}$ for 3 days and corrected for salt content. Pigment concentrations (vertical profile and top centimetre values) were measured on sediment sections that were freeze-dried in the dark for $72 \mathrm{~h}$. The method of pigment analysis is described below for water samples.

Water samples (1 l each) for measurements of SPM (Suspended Particulate Matter), PIM (Particulate Inorganic Material), POM (Particulate Organic Material), chl $a$ and phaeopigment concentrations were filtered immediately through pre-combusted $\left(450{ }^{\circ} \mathrm{C}\right)$ and pre-weighed Whatman GF/C filters. Filters for SPM measurements were pre-combusted (450 ${ }^{\circ} \mathrm{C}$ ), weighed, then after filtering of the water sample was complete, dried at $50{ }^{\circ} \mathrm{C}$ for 3 days and re-weighed, then re-combusted and finally re-weighed a second time for the organic fraction evaluation (POM).

Filtered material for pigment measurements were frozen at $-80{ }^{\circ} \mathrm{C}$ until extraction and analysis. Pigments were extracted from filters into methanol (80\%) for 1 hour in the dark at 4 ${ }^{\circ} \mathrm{C}$. The methanol solution was centrifuged and fluorescence of the supernatant was measured before and after acidification with 2 drops of $\mathrm{HCl}(10 \mu \mathrm{l}$ for $1 \mathrm{ml}$ of $\mathrm{MeOH})$ with a Turner Fluorometer. Total chl $a$ and the phaeopigments were calculated according to Lorenzen (1967).

For each experiment, the time series of probe SPM and pigment concentrations were calibrated from the set of 28 measured values (2 replications for each current increment). Data from the "ridge" and "runnel" experiments were considered separately for the probe calibration ( $\mathrm{r}^{2}=0.77$ for "ridge" and $\mathrm{r}^{2}=0.92$ for "runnel" experiments). Resuspension SPM data were converted into sediment mass eroded per unit area ( $M$ in $\left.\mathrm{kg} \mathrm{m}^{-2}\right)$ according to the 
formula: $M=S P M V / S$ where $V$ is the flume volume $\left(\mathrm{m}^{3}\right)$ and $S$ is the test section surface area $\left(\mathrm{m}^{2}\right)$.

\section{Model fits}

The parameters of all equations were identified by minimisation of the ordinary least squares (OLS) criterion, using a direct search (simplex of Nelder and Mead, 1965). Differential equations were integrated analytically for computations. The mean square error (MSE) matrix was chosen as a measure of the accuracy of the estimates. The MSE matrix has been computed by resampling the centred residuals, using the bootstrap method (Efron, 1979). All calculations were performed with the software package Matlab.

\section{Results}

\section{Sediment properties}

Sediment moisture contents (0-1 cm interval) differed between the prepared ridge and runnel sediments with mean values of 176 and 213\%, respectively. For each test bed, sediment moisture contents in the top centimetre also differed between individual experiments (One way ANOVA, with $p=0.0001$ ) (Table 1). The fluidisation of the interface might have been affected by the meiofauna, which were not removed. The vertical profiles of sediment concentration in cores collected on ridges and in runnels at the field site in Marennes-Oléron Bay, (Fig. 1b) showed no significant differences with depth for ridge sediments (One way ANOVA, $n=3, p=0.124$ ), but significant differences for runnel sediments (Fig. 1c; One way ANOVA, $n=6, p=0.0001)$.

Both sediment concentration and moisture content at the interface were calculated for each test bed (Table 1). In ridge experiments, sediment concentrations were estimated to be equal to sediment concentrations in the uppermost centimetre. In runnel experiments, 
sediment concentrations at the interface were unknown initially, and different from sediment concentrations at the first top centimetre. The millimetre-scale profile (Fig. 2b) of runnel-type control sediment provided estimates of sediment concentrations at the interface. The ratio of the sediment concentration in the uppermost centimetre divided by the sediment concentration measured at the interface was applied to sediment concentrations in the uppermost centimetre. This enabled us to estimate a sediment concentration at the interface for each experiment (Table 1). The same calculation was applied for estimating sediment moisture contents at the interface.

Algal pigment depth profiles (Fig. 3a) did not show any depth trends for the ridge-type sediments (One way ANOVA, $\mathrm{P}=0.065$ ). The mean values recorded for ridge experiments were $c a .6$ and $7 \mu \mathrm{g}_{\text {pigment. }}$ ssediment $^{-1}$ for the chl $a$ and the phaeopigments, respectively. Similarly, the mean values for runnel experiments were in the range of $6-8 \mu g_{\text {pigment. }}$ sediment $^{-1}$, with significantly lower values at the surface (Fig. 3b) indicating occurrence of photooxydative processes responsible for pigments degradation. In such conditions, microalgal biomass was unlikely to produce an active photosynthetic biofilm with stabilising effects.

\section{Resuspension results}

The results of the erosion experiments are plotted as the change in eroded sediment mass ( $M$ in g. $\mathrm{m}^{-2}$ ) recorded as the current speed was increased in the flume (Fig. 4). No mass erosion occurred under the experimental conditions. The observed erosion consisted of the resuspension of aggregates mainly from the snail tracks (defined as a biogenic fluff layer in Orvain et al., 2003).

The control sediment test beds reached an erosion threshold when the current speed was $23 \mathrm{~cm} . \mathrm{s}^{-1}$ (corresponding to a bed shear stress of $0.2 \mathrm{~Pa}$ ) and the eroded sediment mass 
increased for current speeds greater than this critical value until the end of each experiment (Figs. 4a and 4b). At each velocity increment above the critical threshold value, an asymptotic value of eroded mass was reached within 10 minutes of the velocity change. The maximum amounts of eroded sediment mass were lower for the ridge $\left(0.5 \mathrm{~g} \cdot \mathrm{m}^{-2}\right)$ than for runnel $\left(8 \mathrm{~g} \cdot \mathrm{m}^{-}\right.$ ${ }^{2}$ ) sediments in the control test sediment beds.

The sediment masses eroded from ridge and runnel sediments in the presence of different snail densities had patterns similar to the control beds. For each velocity increment, the maximum asymptotic mass of eroded sediment varied with the snail density and for any given snail density and current speed, the mass eroded was always lower from ridge-type sediments than for runnel-type sediments. The maximum values of eroded mass were obtained at the highest snail density of 50,000 ind. $\mathrm{m}^{-2}$ (values of 6 and 27 g.m $\mathrm{m}^{-2}$ for ridge and runnel sediments, respectively).

Variability between two replicates of the same treatment was lower for ridge-type sediments (Fig. 4a) than for runnel-type sediments (Fig. 4b). Although this variability could be due to the mud preparation procedure for the runnel sediments, the potential influence of variability in the sediment moisture content was controlled for (Table 1).

Fluorimetry time series data were similar to those for the eroded sediment mass (data not shown). However, our data also exhibited evidence of the influence of animal activity on the quality of resuspended material and that the erosion kinetics for sediment and microalgae was different. The quality of the resuspended material was characterized at the end of every current increment by using the ratio of the pigment concentration $\left(\mu \mathrm{g}_{\text {pigment. }} .^{-1}\right)$ to the sediment

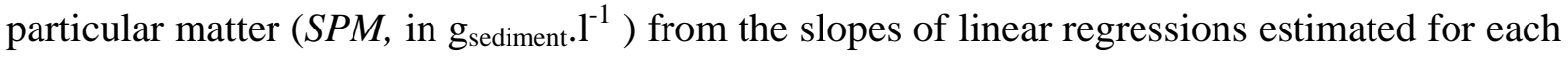
flume experiment. A significant positive relationship (Fig. 5) was found between this ratio and the snail density for the ridge-type sediments $\left(y=7.10^{-4} x+12.9, r^{2}=0.88, n=10\right)$. The mean pigment : SPM ratio for the ridge control sediments was $12.9 \mu$ g pigment.g sediment ${ }^{-1}$, and is 
equivalent to the mean value obtained within the sediment bed (13 $\mu g_{\text {pigment. }}$ gsediment $^{-1}$; Fig. 3a). No correlation was found between this ratio and the snail population density for the runneltype sediment experiments (Fig. 5); the pigment : SPM ratio measured during the experiments was slightly more than double the ratio found for the control sediment on depth profiles (ca. $12 \mu \mathrm{g}_{\text {pigment. }}$ gsediment $^{-1}$, see Fig. 3b).

Qualitative differences in the resuspended microalgal biomass (expressed as the ratio of phaeopigment to chl $a$ concentrations) varied as bed shear stress increased over the course of experiments (Figs. 6a and 6b) and the general trends were always similar. In experiments with ridge-type sediments (Fig. 6a), the ratios generally increased and converged to a value of ca. 4 at the end of the experiment. The relationship between phaeopigment and chl $a$ concentrations (Fig. 7a) was highly significant with a regression slope of ca. 3.4.

In experiments with runnel-type sediments (Fig. 6b), the ratios increased with increasing bed shear stress up to $0.99 \mathrm{~Pa}$ (ratio ca. 4), after which there appeared to be a levelling off or a decrease in the ratios. The relationship between chl $a$ and phaeopigment concentrations appeared different at two different stages: (1) data within the same interval as the ridge (chl $a$ concentration within the range $<0.05 \mu \mathrm{g} \cdot \mathrm{l}^{-1}$, Fig. $7 \mathrm{~b}$ ) and (2) data above 0.05 $\mu$ g. $\mathrm{l}^{-1}$ chl $a$ (Fig. 7c). The second data subgroup (Fig. 7c) had a highly significant linear relationship but with a lower slope (ca. 1). This is similar to the ratio found in both types of sediments, even near the water-sediment interface (Figs. 3a and 3b). The first data subgroup (Fig. 7b) had a significant linear relationship between phaeopigment and chl $a$ concentrations with a slope equal to 3.8, similar to the slope estimated for the ridge-type sediments. This reveals that the resuspended bioturbated sediment was characterised by high pigment concentration values with enrichment in phaeopigments. Resuspension of underlying nonbioturbated sediment (corresponding to data above $0.05 \mu \mathrm{g} . \mathrm{l}^{-1}$ chl $a$ on Fig. 7c) was characterised by a ratio of phaeopigment to chl $a$ concentrations, close to the controls (Fig. 3). 


\section{Model description}

The model is based on the analysis of the eroded mass kinetics and, as we have seen (Fig. 4) the effects of bioturbation on sediment resuspension depend on both the snail density and the surficial sediment concentration.. Since our experiments were similar to those in Willows et al. (1998) with Macoma balthica, we used the equation system they proposed (after modification since they used infinite velocity while we used shear velocity as physical forcing). This modification (Eq. 2) implies that the values of one parameter ( $\beta$ ) cannot be compared between both studies. All the parameters used in the equation system discussed below are listed in Table 2.

The eroded mass level increased until an asymptotic value $\max M\left(u^{*}, n\right)$, during one increment in current velocity (Fig. 8a) regardless of the tested snail density ( $n$ ) and the friction velocity $\left(u^{*}\right)$ greater than the critical friction velocity for erosion $\left(u^{*}\right)$. Thus, a progressive decline in erosion rates occurred as the mass of suspended sediment approached $\max M\left(u^{*}, n\right)$. This suggests a model where the rate of erosion is proportional to the difference between the amount of sediment eroded from the bed $(M)$ and the amount of sediment that is potentially available for erosion $\max M\left(u^{*}, n\right)$ :

$$
\frac{d M}{d t}=k\left[\max M\left(u^{*}, n\right)-M\right] \quad \text { when } M<\max M\left(U^{*}, n\right) \text {; }
$$

otherwise,

$$
\frac{d M}{d t}=0
$$

where the parameter $k$ is the specific erosion rate.

At all snail densities tested, the asymptotic amount $\max M\left(u^{*}, n\right)$ was a sigmoid curve as a function of the excess friction velocity $\left(u^{*}-u^{*}\right)$. This relationship is described by a cumulative Weibull function for the standardised $\max M\left(u^{*}, n\right)$ (Fig. 8b): 


$$
Q=\frac{\max M\left(u^{*}, n\right)}{\max M\left(U^{*}, n\right)}=1-\exp ^{-\left[\left(u^{*}-u^{*}{ }_{c}\right) / \beta\right]^{\alpha}} \quad\left(\mathrm{u}^{*}>\mathrm{u}^{*}{ }_{\mathrm{c}}\right)
$$

where $\left(u^{*}-u_{c}^{*}\right)$ represents the excess friction velocity over the critical threshold friction velocity for erosion $\left(\mathrm{m} . \mathrm{s}^{-1}\right)$ and $\max M\left(U^{*}, n\right)$ represents the maximum value of $\max M\left(u^{*}, n\right)$ as $u^{*}$ approaches infinity.

The asymptotic concentration of $M, \max M\left(U^{*}, n\right)$ also varied with the snail density. Thus, the 3 parameter version of Willows model describes (for a given density of the bioturbating organism, in this case Hydrobia ulvae) that the resuspended sediment mass saturates exponentially at $\max M\left(U^{*}, N\right)$ for a velocity fixed by $v($ Fig. $8 c)$ :

$$
\max M\left(U^{*}, n\right)=\max M\left(U^{*}, 0\right)+\left[\max M\left(U^{*}, N\right)-\max M\left(U^{*}, 0\right)\right] \cdot\left(1-\exp ^{-v \cdot n}\right)
$$

\section{Model parameter estimation and variability analysis}

Three sets of equations were tested by successively improved global fits to the experimental data at each stage. Three parameter sets (Table 3) were fitted. We first tested the model proposed by Willows et al. (1998) by minimisation of $2 \times 6$ parameters on the experimental results and analyzing ridge and runnel sediments, separately. In order to add a new variable for sediment moisture content to the equations, we tested an "8-parameter model" on pooled ridge and runnel data. Finally, we improved the fit of this "8-parameter model” by considering two different values of the $\beta$ parameter for ridge and runnel sediments in a "9-parameter model”.

\section{$\underline{2 \times 6-p a r a m e t e r ~ m o d e l ~ d e v e l o p m e n t ~}$}

For reproducing the observed resuspension of ridge sediments, we applied a stepwise approach to determine the parameter which explained most of the measured variability between the parameters $\left(\alpha, \beta, k, \max M\left(U^{*}, n\right)\right.$ and $\left.\max M\left(U^{*}, 0\right)\right)$ of Eqs. 1 and 2 . The most sensitive parameter was $\max M\left(U^{*}, n\right)$ and it explained $99 \%$ of the variability. As described by 
Willows et al. (1998), the parameter $\beta$ explained most of the remaining variability. Application of the same statistical method to the experimental results from the runnel-type sediments gave the same results. Two 13-parameter models (with ten independent values of $\max M\left(U^{*}, n\right)$ and one single common value for $\alpha, \beta$ and $k$ ) were thus adopted having $r^{2}=$ 0.978 and $r^{2}=0.985$, for ridge- and runnel-type sediments, respectively. After providing estimates of $\alpha, \beta$ and $k$ and ten $\max M\left(U^{*}, n\right)$ values for both "ridge" and "runnel” 13parameter models, we minimized the parameters in Eq. 3, which allowed the dependence of snail density on $\max M\left(U^{*}, n\right)$ to be included (Fig. 9).

This parameterisation provided a good fit to $\max M\left(U^{*}, n\right)$ (see Fig. 9 and Table 3). The 2×6-parameter model (Table 3), equivalent to the model proposed by Willows et al. (1998), reproduced satisfactorily the set of $10 \times 1120$ eroded mass data from ridge and runnel sediments (Figs. 10a and 10b with $r^{2}=0.904$ and $r^{2}=0.883$, respectively, see also Table 3).

\section{“8-parameter model” development}

The difference between -“runnel” and "ridge” sediments was the initial sediment moisture contents at the sediment-water interface; snail density and moisture content are expected to interact to modify the amount of resuspended sediment $\max M\left(U^{*}, n\right)$. To include moisture content in the model, the relationship between $\max M\left(U^{*}, n\right)$ and moisture content was described (Fig. 11). Consequently, to respect the definition of $\max M\left(U^{*}, N\right)$ and its units (g.m ${ }^{-2}$ ), the moisture content, W, was integrated into Eq. 3 as:

$$
\max M\left(U^{*}, n\right)=\max M\left(U^{*}, 0\right)+\left[\max M\left(U^{*}, N\right)-\max M\left(U^{*}, 0\right)\right] \times\left(1-\exp { }^{-v \cdot n \cdot \exp (\mathcal{W})}\right)
$$

In order to test the extent to which intra- and inter- "ridge" and "runnel” variability can be ascribed to variations of moisture content we pooled "ridge” and "runnel” data and using Eq. 4 created a single model, accounting for differences between "ridge" and "runnel” data. All parameters of Eq. 4 were fitted by comparing to the estimate of $\max M\left(U^{*}, n\right)$. This model yielded a significantly better fit than $2 \times 6$-parameter model for "runnel” experiments $\left(r^{2}=0.867\right.$ 
instead of $r^{2}=0.744$ for $2 \times 6$-parameter model), but it was over-parameterised for the "ridge" conditions ( $r^{2}=0.827$ inferior to $r^{2}=0.869$ for $2 \times 6$-parameter model). These results confirmed that the introduction of the sediment moisture content into the equation system improved the fit for "runnel" experiments. For the eroded masses, we obtained a better adjustment with this single "8-parameter model" (Table 3) as compared to 2×6-parameter model for runnels $\left(r^{2}=0.896\right.$ instead of $\left.r^{2}=0.883\right)$. However, the adjustment of computed results to all data underestimated the "ridge” results $\left(r^{2}=0.344\right)$.

\section{“9-parameter model” development}

The underestimation of ridge results by the "8-parameter model" was attributed to the different patterns of resuspension from ridge and runnel-type sediments. The final minimisation was completed using two different values of $\beta$ for ridge and runnel models (Figs. 12a and 12b). We obtained the best fit to both ridge and runnels results with this version of the model $\left(r^{2}=0.912, r^{2}=0.830\right.$ for ridge and runnel sediments respectively, see Table 3). The differentiation of two other parameters (i.e. $\alpha$ and $k$ ) did not improve the fits.

\section{Discussion}

\section{Fluff layer erosion}

Resuspension began at the same critical bed shear stress $(0.20 \mathrm{~Pa})$ regardless the moisture content values tested. While the critical shear stress for mass erosion is dependent on the sediment moisture content of cohesive sediments (Migniot 1968), no mass erosion was observed during our experiments. These results are consistent with observations made by Andersen (2001) who also described a direct relationship between erosion rates at low shear stresses and pelletisation intensity by H. ulvae on the Danish Wadden Sea mudflats.

By loosening and turning over the sediment, Hydrobia ulvae contributes to the production of a more erodible surface fluff layer of sediment from a less-erodible matrix (Orvain et al. 2003). Deeper layers of reconstituted sediment possess significantly greater 
shear strengths to resist erosion at the highest experimental bed shear stresses as shown and modeled by Orvain et al. (2003). Presumably, at some higher bed shear stresses, further erosion will eventually occur leading to the occurrence of «type I » or «type II » erosion described by Amos et al. (1992) and Houwing (1999). We assume that bioturbation effects must play a very significant role in resuspension fluxes especially for consolidated cohesive beds, for which no bed failure generally takes place in the field.

During grazing, Hydrobia ulvae breaks up surface sediments, contributing to the deposition of a mucus- and pellet-rich, easily erodible surface layer created from an underlying more cohesive sediment (Orvain et al. 2003). According to the classical "type I" erosion, there is an exponential increase of the eroded mass (Mehta et al., 1982; Amos et al., 1992). Our results showed such an exponential increase at the start of resuspension (for example, when bed shear stresses are less than 0.52 Pa see Fig. 4) and thus the equation for classical "type I" erosion (Mehta et al., 1982; Amos et al., 1992) could guarantee a good fit to our experimental data only in this interval of bed shear stresses. However, for other curves in our dataset (Fig. 4) a linear relationship between asymptotic concentrations $\max M\left(U^{*}, n\right)$ and higher bed shear stresses was observed, and the remaining curves showed a gradual reduction of erosion rate when the highest bed shear stresses were applied. The sigmoid pattern in our results led us to adopt the equation system proposed by Willows et al. (1998) who analysed results from a similar set of experiments with the bivalve, Macoma balthica.

The model tested (Eqs. 1 and 2) and developed by Willows et al. (1998) is appropriate for describing this type of erosion process. Bioturbated surface layers enriched in faecal pellets behave more like a suspension with gradual shear-induced disruption and resuspension. Mucus-rich floc begins to roll over the bed surface when the critical bed shear stress is exceeded gradually breaking up as bed shear stress increases. This may be related to specific properties of mucus tracks and their biochemical composition (Denny, 1983). , The 
maximum asymptotic concentration $\max M\left(U^{*}, n\right)$ is reached at high velocities $\left(u^{*} \rightarrow \infty\right)$, which corresponds to disruption and complete resuspension of the entire volume of flocs and pellets produced by the animal population. The deterministic model by Orvain et al. (2003) is also appropriate to describe this gradual erosion process of an enriched mucus fluff layer.

In addition to bioturbator density, the influence of the initial sediment moisture content on the amount of resuspended sediment $\max M\left(U^{*}, n\right)$ (Fig. 11) was also tested in our study. We have assumed that Hydrobia ulvae bioturbation and track formation are two related processes and that the previously determined direct relationship between sediment moisture content and track formation (Orvain and Sauriau 2002; Orvain et al., 2003) indirectly affects the formation of the bioturbated sediment layer and its subsequent resuspension studied here. The results suggested a relationship between both moisture content and the snail population density (Fig. 11), and a new equation system has been proposed with both factors (Eq. 4). Although the sediment moisture content did not explain all the variability between replicates (Table 3 and Fig. 12), including the moisture content as a variable explained substantial portions of the residual variations between snail density-replicates (see Table 3). Addition of a parameter for moisture content means the model requires only 9 parameters instead of the $2 \times 6$ parameters needed for the initial model. We assume that Hydrobia ulvae bioturbation activities and track formation are two interrelated features and the direct influence of sediment moisture content on track formation (Orvain and Sauriau, 2002) bring about indirect effects of the bioturbated sediment layer and subsequent resuspension studied here.

\section{Generalising the model to different species}

Equations developed by Willows et al. (1998) are suitable for describing the consequences of bioturbation activities by Hydrobia ulvae on the resuspension of muddy sediments in both runnel and ridge systems. The $2 \times 6$-parameter model (Fig. 10) is equivalent 
to the Willows' model, except that Willows et al. (1998) used flow velocity measured at a fixed reference height above the bed as a model variable while we have used an estimate of the friction velocity. This modification affects the value of the $\beta$ parameter, nevertheless a direct comparison between the computation of $\max M\left(U^{*}, n\right)$ by both the ridge and runnel 2×6-parameter models and the model as developed by Willows et al. (1998) for Macoma balthica can be made (Fig. 13). With the $M$. balthica model, the standardised plateau $\max M\left(U^{*}, N\right)$ was higher at a lower animal densities than that of $H$. ulvae model; possible explanations include: (1) differences in bioturbation time, (2) sediment moisture content and (3) differences in bioturbation rates by the two species.

(1) Bioturbation time in Willows et al. (1998) was 24 hours compared to 5 hours in our caseBioturbation time could be a relevant factor to explain bioturbation activities as this is the case for track formation (Orvain and Sauriau, 2002) and as in tracer mixing models where the sediment mixing is expanded to diffusion analogy (Matisoff, 1982). New experiments have to be carried out to reconsider Eqs. 3 and 4 in further model developments.

(2) As we have shown here the relevance of moisture content on the amount of sediment easily resuspended and produced through Hydrobia ulvae bioturbation activities (Figs. 4 and 11), we can suggest the same feature for Macoma balthica. New experiments could be carried out in order to test whether sediment moisture content is also a relevant factor influencing the amount of sediment bioturbated by $M$. balthica and to test whether Eq. 4 can be used to describe such an influence for this species. The bivalve Scrobicularia plana has a similar feeding behaviour as Macoma balthica and its bioturbation activity depends on moisture content (Orvain, 2004).

(3) The known processes involved in a benthos-generated fluff layer production are similar for all the deposit-feeder species (Rhoads and Young, 1970; Davis, 1993, Orvain, 2004), even though the mechanisms by which the organisms affect sediment properties differ. 
These mechanisms may include burrowing (changes in sediment consolidation) and/or pelletisation of egested sediment and production of mucus bound pseudofecal strings (addition of a biogenic matrix to the sediments). With respect to one description of bioturbators (Swift, 1993), Hydrobia ulvae and Macoma balthica do not belong in the same bioturbator class, because: (i) they do not capture particles in the same way (they are both deposit-feeders but $M$. balthica is also a facultative suspension feeder), (ii) their burrowing depths are not equivalent ( $H$. ulvae is a surface species and $M$. balthica is a subsurface species) and (iii) their movements are very different (H. ulvae is a very active gastropod that moves horizontally over the bed surface and the lateral movements of $M$. balthica are very limited compared to their vertical displacements). The mass of bioturbated sediment, including the material that is processed by the organism and disrupted by burrowing, is thus expected to be more important for $M$. balthica than for $H$. ulvae and the longer bioturbation time in Willows et al. (1998) experiments (24 hours as compared to 5 hours in our study) would augment significantly the accumulated amount of bioturbated material compared to our experiments. However, Widdows et al. (2000) have shown a marked impact of $M$. balthica on sediment erodability even after only 3h of bioturbation.

These results represent an additional contribution to general models describing the effects of the major components of the benthic community on hydrogeological processes in muddy sediments. Our results only concern the production of a bioturbated surface layer by one type of deposit-feeder and we have not, for example, evaluated the potential for Hydrobia ulvae to modify bed roughness by the protrusion of their shells above the sediment-water interface. Jumars and Nowell (1984) have emphasised the difficulties in using functional groups to describe bioturbation and thus the problems in arriving at an overall description of bioturbation processes for an entire benthic community. However, Orvain (2004) has shown that a model for bioturbation and sediment transport can be used for species belonging to 
different bioturbator class. The present study confirms that a similar model can be applied to different bioturbator categories. Other deposit-feeders, such as sedentary oligochaete and spionid tubes present in ridge structures, may have the opposite effect of consolidating subsurface sediment layers (Davey and Partridge, 1998). In this case, the model proposed by Orvain et al. (2003) cannot be applied and equations must be modified in consequence.

\section{Characterisation of bioturbated layers}

Pigment concentration results showed significant differences within the easily resuspended sediment compared to the more resistant underlying sediment matrix (Figs. 5, 6 and 7). First, resuspended sediments were characterised by enrichment in total pigment concentration (Fig. 5). This highlights the accumulation of pigments in the bioturbated layers as the ratios of pigment concentration to SPM in water column of control experiments were close to those obtained at the sediment-water interface. Such an influence could not be exhibited for runnel data, for which ratios were high with or without animals. Actually, the influence of animals on pigment resuspension seems to be mediated through sediment moisture content at the sediment-water interface. Contrary to ridges, high amount of aggregates enriched in pigments were present at the interface of runnel sediments even without animals. Since pigment accumulation could occur without animals in runnels, bioturbation processes may thus enhance total pigment accumulation via the amount of aggregates present at sediment surface. The sediment bioturbated by Hydrobia ulvae seems to provide a local environment where diatom accumulation and/or production is stimulated. In our experimental conditions, the chl a biomass was very low and diatoms did not develop a biofilm. The analysis of the vertical profile within the sediment bed did not reveal such an accumulation. However, active diatoms which were close to the interface may be sensitive to light stimulation, causing them to migrate to the surface and this should explain the highest 
chla content in the bioturbated layers. Orvain et al. (2004) demonstrated that bioturbation by Hydrobia ulvae significantly affect microphytobenthus accumulation at the surface and resuspension, when diatoms form a biofilm in exponential growth.

Hydrobia ulvae bioturbation directly influences the quality of resuspended pigment concentrations. Resuspension of bioturbated surficial sediment was characterised by higher ratios of pheopigment to chl $a$ concentrations compared to those at the sediment-water interface (Figs. 6 and 7). This pattern can be drawn for resuspension results in ridge and runnel sediments. As for runnel sediments, resuspended material does not only consist of an erosion of bioturbated layers and non-bioturbated sediment resuspension that occurs after resuspension of bioturbated layers clearly entails a decrease in the ratio of phaeopigment to chl $a$ (Fig. 6b, 7b and 7c). Similar observations were reported from in situ flume experiments performed in Westerschelde estuary, SW Netherlands (Lucas et al., 2000). An increase in phaeopigments is consistent with the so called "sloppy feeding” of some deposit-feeders (e.g. Bianchi et al., 1968; Barranguet et al., 1996) and especially for Hydrobia ulvae (LôpezFigueroa and Niell, 1987) in which phaeopigments accumulate in pseudofaeces and faeces.

\section{Describing resuspension of bioturbated layers in a sediment transport model}

The "9-parameter model” gave the best agreement with our data by considering simultaneously animal densities, sediment moisture contents, and bed shear stresses (Table 3). However we prefer the "8-parameter model" for describing the influence of Hydrobia ulvae bioturbation activities in muddy habitats where no runnel-ridge system exists. In mudflat ecosystems where the snail density is important, both snail density and sediment moisture content could now be included in large-scale sediment transport models, with additional information on the spatio-temporal variations of both factors (Widdows et al., 2000; Andersen, 2001). The present study was based on conditions at Marennes-Oléron Bay, but 
may now be extended to investigate sediment transport in other ecosystems where $H$. ulvae is important such as in the Danish Wadden Sea (Andersen 2001).

Quantifying the contribution of bioturbation to sediment erosion on the ecosystem scale is a goal of ours, which encourages us to incorporate equations quantifying the very initial stages of erosion into a most complex numerical model integrating all physical processes and their interactions (Orvain et al., 2003; Orvain, 2004). Indeed, bulk density (Migniot, 1968), particle size (Dade et al., 1992), sand and mud mixture (Houwing, 1999, van Ledden et al., 2003), mud temperature, aerial exposure of the bed (Amos et al., 1988), waves (Grant and Madsen, 1986) and bedform presence (Whitehouse et al., 2000) are major contributing factors known to influence sediment resuspension. Other biological processes have also to be taken into account, such as substrate roughness modifications $\left(\mathrm{z}_{0}\right)$ by biogenic structures (Rhoads and Young, 1970).

\section{Conclusions}

It is now recognized that large-scale sediment transport models must include the effects of biota on sediment properties (Andersen, 2001; Wood and Widdows, 2002). The present paper extends the Willows et al. (1998) model with the addition of sediment water content as an explicit parameter. Bioturbation by the common mud snail, Hydrobia ulvae, is affected by the sediment water content, and extending the model improved the fits to experimental flume data. This suggests that on intertidal mudflats the relationships between bioturbation and environmental parameters that vary with respect to tidal cycles should be investigated further (Orvain et al., 2003). Application of the model at the scale of an ecosystem will require the population dynamics of important bioturbators and spatio-temporal variability in sediment water content (and thus sediment cohesiveness) be evaluated.

\section{Acknowledgements}


This study has been carried out within the framework of the EU-MAST3 project INTRMUD (MAS3-CT95-0022). The Regional Council of Poitou-Charente and IFREMER have financially supported the study by a doctoral grant awarded to F.O. We are grateful to M. Bréret, L. Joassard and B. Thierry for providing valuable advice and help during laboratory flume experiments. 


\section{References.}

Amos, C.L., Brylinsky, M.T., Sutherland, F., O’Brien, D., Lee, S. and Cramp. A., 1998. The stability of a mudflat in the Humber estuary, South Yorkshire, UK. In: Black, K.S., Paterson, D.M., Cramp, A. (Eds.), Sedimentary processes in the intertidal zone. Geological Society, London, Special Publication 139, 25-44.

Amos, C.L., Grant, J., Daborn, G.R., Black., K., 1992. Sea Carousel-a benthic, annular flume. Estuarine Coastal Shelf Sci. 34, 557-577.

Amos, C.L., van Wagoner, N.A., Daborn, G.R., 1988. The influence of subaerial exposure on the bulk properties of fine-grained intertidal sediment from Minas Basin, Bay of Fundy. Estuarine Coastal Shelf Sci. 27, 1-13.

Andersen, T.J., 2001. Seasonal variation in erodability of two temparate, microtidal mudflats. Estuarine Coastal Shelf Sci. 53, 1-12.

Anderson, F.E., 1983. The Northern muddy intertidal: seasonal factors controlling erosion and deposition - a review. Can. J. Fish. Aquat. Sci. 40, 143-159.

Ariathurai, R., Krone., R.B., 1976. Finite element model for cohesive sediment transport. J. Hydraul. Div. ASCE 102, 323-338.

Barranguet, C., Plante-Cuny, M.R., Alivon, E., 1996. Microphytobenthos production in the Gulf of Fos, French Mediterranean coast. Hydrobiologia 333, 181-193.

Bianchi, T.S., Johansson, B., Elmgren, R., 1968. Breakdown of phytoplankton pigments in Baltic sediments: effects of anoxia and loss of deposit-feeding macrofauna. J. Exp. Mar. Biol. Ecol. 251, 161-183.

Blanchard, G.F., Sauriau, P.-G., Cariou-Le Gall, V., Gouleau, D., Garet, M.-J., Olivier, F. 1997. Kinetics of tidal resuspension of microbiota: testing the effects of sediment cohesiveness and bioturbation using flume experiments. Mar. Ecol. Prog. Ser. 151, 1725. 
Dade, W.B., Self, R.L., Pellerin, N.B., Moffet, A., Jumars, P.A., Nowell, A.R.M., 1996. The effects of bacteria on the flow behavior of clay-seawater suspensions. J. Sed. Res. 66, 39-42.

Davey, J.T., Partridge, V.A., 1998. The macrofaunal communities of the Skeffling muds (Humber estuary), with special reference to bioturbation. In: Black, K.S., Paterson, D.M., Cramp, A. (Eds.), Sedimentary processes in the intertidal zone. Geological Society, London, Special Publication 139, 115-124.

Davis, W.R., 1993. The role of bioturbation in sediment resuspension and its interaction with physical shearing. J. Exp. Mar. Biol. Ecol. 171, 187-200.

Delgado, M., de Jonge, V.N., Peletier, H., 1991. Experiments on resuspension of natural microphytobenthos populations. Mar. Biol. 108, 321-328.

Denny, M., 1983. Molecular biomechanics of molluscan mucous secretion. In: Hochachka, P.W. (Ed.), The Mollusca vol. 1. Metabolic biochemistry and molecular biomechanics. Academic Press, London, pp. 431-465.

Dyer , K.R., Christie, M.C., Wright, E.W., 2000. The classification of intertidal mudflats. Cont. Shelf Res. 20, 1039-1060.

Eckman, J.E., Nowell, A.R.M., Jumars, P.A., 1981. Sediment destabilization by animal tubes. J. Mar. Res. 39, 361-374.

Efron, B., 1979. The 1977 Rietz lecture. Bootstrap methods: an other look at the jack-knife. Annal. Stat. 7, 421-449.

Ehrhold, A., Blanchard, M., Auffret, J.-P., Garlan, T., 1998. Conséquences de la prolifération de la crépidule (Crepidula fornicata) sur l’évolution sédimentaire de la baie du MontSaint-Michel (Manche, France). C. R. Acad. Sci. Paris, Life Sciences 327, 583-588.

Galois, R., Blanchard, G., Seguignes, M., Huet, V. , Joassard, L., 2000. Spatial distribution of sediment particulate organic matter on two intertidal mudflats: a comparison between 
Marennes-Oléron Bay (France) and the Humber estuary (UK). Cont. Shelf Res. 20, 1199-1217.

Gerdol, V.,, Hughes, R.G., 1994. Effect of Corophium volutator on the abundance of benthic diatoms, bacteria and sediment stability in two estuaries in southeastern England. Mar. Ecol. Prog. Ser. 114, 109-115.

Germaneau, J., Sauriau P.-G., 1996. La mer des pertuis : un système topographique filtrant les agents météorologiques. Bull. Soc. Sci. Nat. Ouest France, nouvelle série 18, 53-68

Gouleau, D., Jouanneau, J.M., Weber, O., Sauriau, P.-G., 2000. Short- and long-term sedimentation on Montportail-Brouage intertidal mudflat, Marennes-Oléron Bay (France). Cont. Shelf Res. 20, 1513-1530.

Grant, D., Madsen, O.S., 1986. The continental-shelf bottom boundary layer. Annu. Rev. Fluid Mech. 18, 265-305.

Grant, J., Bathmann, U.V., Mills, E.L., 1986. The interaction between benthic diatom films and sediment transport. Estuarine Coastal Shelf Sci. 23, 225-238.

Grant, J., Daborn., G., 1994. The effects of bioturbation on sediment transport on an intertidal mudflat. Neth. J. Sea Res. 32, 63-72.

Haubois, A.-G., Guarini, J.-M., Richard P., Blanchard, G.F., Sauriau, P.-G, 2002. Spatiotemporal differentiation in the population structure of Hydrobia ulvae on an intertidal mudflat (Marennes-Oléron Bay, France). J. Mar. Biol. Ass. U.K. 82, 605-614.

Houwing, E.-J., 1999. Determination of the critical erosion threshold of cohesive sediments on intertidal mudflats along the Dutch Wadden Sea Coast. Estuarine Coastal Shelf Sci. 49, 545-555.

Jumars, P.A., Nowell, A.R.M., Self, R.F.L., 1981. A simple model of flow-sedimentorganism interaction. Mar. Geol. 42, 155-172. 
Jumars, P.A.,, Nowell, A.R.M., 1984. Effects of benthos on sediment transport: difficulties with functional grouping. Cont. Shelf Res. 3, 115-130.

Laima, M., Maksymowska-Brossard, D., Sauriau, P. G., Richard, P., Girard, M., Gouleau, D., Joassard, L., 2002. Fluff deposition on intertidal sediments: effects of benthic biota, ammonium fluxes and nitrification rates. Biogeochemistry 61, 115-133.

Levinton, J.S., Lopez, G.R., 1977. A model of renewable resources and limitation of depositfeeding benthic populations. Oecologia 31, 177-190.

Lôpez-Figueroa, F., Niell, F.X., 1987. Feeding behaviour of Hydrobia ulvae (Pennant) in microcosms. J. Exp. Mar. Biol. Ecol. 114, 153-167.

Lorenzen, C., 1967. Determination of chlorophyll and phaeopigments spectrophotometric equations. Limnol. Oceanogr. 12, 343-346.

Lucas, C.H., Widdows, J., Brinsley, M.D., Salkeld, P.N., Herman, P.M.J., 2000. Benthicpelagic exchange of microalgae at a tidal flat. 1. Pigment analysis. Mar. Ecol. Prog. Ser. 196, 59-73.

Mc Call, P.L., Tevesz, M.J.S., 1982. The effects of benthos on physical properties of freshwater sediments. In: Mc Call, P.L., Tevesz, M.J.S. (Eds), Animal - sediment relations. Plenum Press, New York, pp. 105-176.

Matisoff, G., 1982. Mathematical models of bioturbation. In: Mc Call, P.L., Tevesz, M.J.S. (Eds.), Animal - sediment relations. Plenum Press, New York, pp. 289-330.

Meadows, P.S., Meadows, A., West, F.J.C., Shand, P.S., Shaikh, M.A., 1998. Mussels and mussel beds (Mytilus edulis) as stabilizers of sedimentary environments in the intertidal zone. In: Black, K.S., Paterson, D.M., Cramp, A. (Eds.), Sedimentary processes in the intertidal zone. Geological Society, London, Special Publication 139, pp 331-347. 
Meadows, P.S., Tait, J., 1989. Modification of sediment permeability and shear strength by two burrowing invertebrates. Mar. Biol. 101, 75-82.

Mehta, A.J., Hayter, E.J., Parker, W.R., Krone, R.B., Teeter, A.M., 1989. Cohesive sediment transport. I: process description. J. Hydraul. Engin. 115, 1076-1093.

Mehta, A.J., Parchure, T.M., Dixit, J.G., Ariathurai, R., 1982. Resuspension potential of deposited beds. In: Kennedy, V.S. (Ed.), Estuarine comparisons. Academic Press, New York, pp. 591-609.

Migniot, C., 1968. Etude des propriétés physiques de différents sédiments très fins et de leur comportement sous des actions hydrodynamiques. Houille blanche 7, 591-620.

Nelder, J.A., Mead, R., 1965. A simplex method for function minimization. Computer J. 7, 308-313.

Nowell, A.R.M., Jumars, P.A., 1984. Flow environments of aquatic benthos. Annu. Rev. Ecol. Syst. 15, 303-328.

Nowell, A.R.M., Jumars, P.A., Eckman, J.E., 1981. Effects of biological activity on the entrainment of marine sediments. Mar. Geol. 42, 133-153.

Orvain, F., 2004. A model of sediment transport under the influence of surface bioturbation: generalisation to the facultative suspension-feeder Scrobicularia plana. Mar. Ecol. Progr. Ser. In press.

Orvain, F., Sauriau, P.-G., 2002. Environmental and behavioural factors affecting bioturbation activities in the intertidal gastropod Hydrobia ulvae. J. Exp. Mar. Biol. Ecol. 272, 191216.

Orvain, F., Sauriau, P.-G., Le Hir P., 2003. A model of fluff layer erosion and subsequent bed erosion in the presence of the bioturbator, Hydrobia ulvae. J. Mar. Res. 61, 823-851. 
Orvain; F., Sauriau, P.-G., Sygut A., Joassard L., Le Hir P., 2004. Interacting effects of Hydrobia ulvae bioturbation and microphytobenthos on the erodability of mudflat sediments. Mar. Ecol. Progr. Ser. 278, 205-223.

Paterson, D.M., 1989. Short-term changes in the erodability of intertidal cohesive sediments related to the migratory behavior of epipelic diatoms. Limnol. Oceanogr. 34, 223-234.

Paterson, D.M., Black, K.S., 1999. Water flow, sediment dynamics and benthic biology. Adv. Ecol. Res. 29, 155-193.

Rhoads, D.C., Young, D.K., 1970. The influence of deposit-feeding organisms on sediment stability and community trophic structure. J. Mar. Res. 28, 150-178.

zone. Geological Society, London, Special Publication 139, 135-148.

Sauriau, P.-G., Mouret, V., Rincé, J.-P., 1989. Organisation trophique de la malacofaune benthique non cultivée du bassin ostréicole de Marennes-Oléron. Oceanol. Acta 12, 193-204.

Sheng, Y.P., Villaret, C., 1989. Modeling the effect of suspended stratification on bottom exchange processes. J. Geophys. Res. 94, 14429-14444.

Swift, D.J., 1993. The macrobenthic infauna off Sellafield (North-Eastern Irish Sea) with special reference to bioturbation. J. Mar. Biol. Assoc. U.K. 73, 143-162.

Underwood, G.J.C., Paterson, D.M., 1993. Seasonal changes in diatom biomass, sediment stability and biogenic stabilization in the Severn Estuary. J. Mar. Biol. Assoc. U.K. 73, 871-887.

Whitehouse, R.J.S., Bassoulet, P., Dyer, K.R., Mitchener, H.J., Roberts, W., 2000. The influence of bedforms on flow and sediment transport over intertidal mudflats. Cont. Shelf Res. 20, 1099-1124. 
Widdows, J., Brinsley, M. D., Bowley, N., Barrett, C., 1998a. A benthic annular flume for in situ measurement of suspension feeding/biodeposition rates and erosion potential of intertidal cohesive sediment. Estuarine Coastal Shelf Sci. 46, 27-38.

Widdows, J., Brinsley, M.D., Salkeld, P.N., Elliott, M., 1998b. Use of annular flumes to determine the influence of current velocity and bivalves on material flux at the sediment-water interface. Estuaries 21, 552-559.

Widdows, J., Brown, S., Brown, M.D., Brinsley, M.D., Salkeld, P.N., Elliott, M., 2000. Temporal changes in intertidal sediment erodability: influence of biological and climatic factors. Cont. Shelf Res. 20, 1275-1289.

Willows, R.I., Widdows J., Wood, R.G., 1998. Influence of an infaunal bivalve on the erosion of an intertidal cohesive sediment: a flume and modeling study. Limnol. Oceanogr. 43, 1332-1343.

Wood, R.G., Widdows, R.I., 2002. A model of sediment transport over an intertidal transect, comparing the influences of biological and physical factors. Limnol. Oceanogr. 47, 848-855.

Yallop, M. L., Paterson, D. M., Wellsbury, P., 2000. Interrelationships between rates of microbial production, exopolymer production, microbial biomass, and sediment stability in biofilms of intertidal sediments. Microb. Ecol. 39, 116-127. 
Table 1 :

\begin{tabular}{|c|c|c|c|c|c|}
\hline & $\begin{array}{l}\text { Hydrobia ulvae } \\
\text { density }\end{array}$ & $\begin{array}{l}\text { Measured sediment } \\
\text { concentration at the } \\
\text { uppermost cm }\left(\mathrm{kg} \cdot \mathrm{m}^{-3}\right)\end{array}$ & $\begin{array}{l}\text { Estimated sediment } \\
\text { concentration at the } \\
\text { interface }\left(\mathrm{kg} \cdot \mathrm{m}^{-3}\right)\end{array}$ & $\begin{array}{l}\text { Measured moisture } \\
\text { content at the } \\
\text { uppermost cm (\%) }\end{array}$ & $\begin{array}{l}\text { Estimated moisture } \\
\text { content at the } \\
\text { interface }(\%)\end{array}$ \\
\hline \multicolumn{6}{|l|}{$\begin{array}{l}\text { Runnel-type } \\
\text { sediments }\end{array}$} \\
\hline & 0 & $\begin{array}{l}423 \\
423\end{array}$ & $\begin{array}{l}339 \\
339\end{array}$ & $\begin{array}{l}198 \\
198\end{array}$ & $\begin{array}{l}258 \\
258\end{array}$ \\
\hline & 1000 & $\begin{array}{l}394 \\
373\end{array}$ & $\begin{array}{l}315 \\
298\end{array}$ & $\begin{array}{l}216 \\
230\end{array}$ & $\begin{array}{l}280 \\
298\end{array}$ \\
\hline & 5000 & $\begin{array}{l}403 \\
370\end{array}$ & $\begin{array}{l}322 \\
296\end{array}$ & $\begin{array}{l}210 \\
233\end{array}$ & $\begin{array}{l}273 \\
301\end{array}$ \\
\hline & 10000 & $\begin{array}{l}408 \\
371\end{array}$ & $\begin{array}{l}326 \\
297\end{array}$ & $\begin{array}{l}207 \\
232\end{array}$ & $\begin{array}{l}269 \\
299\end{array}$ \\
\hline & 50000 & $\begin{array}{l}407 \\
418\end{array}$ & $\begin{array}{l}325 \\
334\end{array}$ & $\begin{array}{l}208 \\
201\end{array}$ & $\begin{array}{l}270 \\
261\end{array}$ \\
\hline \multicolumn{6}{|l|}{$\begin{array}{l}\text { Ridge-type } \\
\text { sediments }\end{array}$} \\
\hline & 0 & $\begin{array}{l}485 \\
482\end{array}$ & $\begin{array}{l}485 \\
482\end{array}$ & $\begin{array}{l}169 \\
170\end{array}$ & $\begin{array}{l}169 \\
170\end{array}$ \\
\hline & 1000 & $\begin{array}{l}422 \\
478\end{array}$ & $\begin{array}{l}422 \\
478\end{array}$ & $\begin{array}{l}200 \\
171\end{array}$ & $\begin{array}{l}200 \\
171\end{array}$ \\
\hline & 5000 & $\begin{array}{l}468 \\
465\end{array}$ & $\begin{array}{l}468 \\
465\end{array}$ & $\begin{array}{l}176 \\
177\end{array}$ & $\begin{array}{l}176 \\
177\end{array}$ \\
\hline & 10000 & $\begin{array}{l}444 \\
482\end{array}$ & $\begin{array}{l}444 \\
482\end{array}$ & $\begin{array}{l}187 \\
170\end{array}$ & $\begin{array}{l}187 \\
170\end{array}$ \\
\hline & 50000 & $\begin{array}{l}475 \\
488\end{array}$ & $\begin{array}{l}475 \\
488\end{array}$ & $\begin{array}{l}173 \\
167\end{array}$ & $\begin{array}{l}173 \\
167\end{array}$ \\
\hline
\end{tabular}




\section{Table 2 :}

\begin{tabular}{|c|c|}
\hline \multicolumn{2}{|l|}{ Variables } \\
\hline$\overline{\mathrm{u}}$ & Free Current velocity at height $=4 \mathrm{~cm}$ above the bottom $\left(\mathrm{m} . \mathrm{s}^{-1}\right)$ \\
\hline $\mathrm{u}^{*}$ & Friction velocity $\left(\mathrm{m} . \mathrm{s}^{-1}\right)$ \\
\hline $\mathrm{U}^{*}$ & $\begin{array}{l}\text { Friction velocity for which } M \text { reached its asymptotic maximum value (maxM( }\left(\mathrm{U}^{*}, \mathrm{n}\right) \text { ) (different } \\
\text { from the maximum shear velocity obtained during experiments). This parameter is used for } \\
\mathrm{u}^{*} \rightarrow \infty \text { in mathematical functions } \operatorname{maxM}\left(\mathrm{U}^{*}, \mathrm{n}\right) \text {. }\end{array}$ \\
\hline M & Sediment mass eroded converted from measured turbidity $\left(\mathrm{g} . \mathrm{l}^{-1}\right)$ in the flume $\left(\mathrm{g} \cdot \mathrm{m}^{-2}\right)$ \\
\hline $\mathrm{n}$ & Hydrobia ulvae numerical density $\left(. \mathrm{m}^{-2}\right)$ \\
\hline $\mathrm{N}$ & $\begin{array}{l}\text { H. ulvae density for which the sigmoid maximum value }\left(\operatorname{maxM}\left(\mathrm{U}^{*}, \mathrm{~N}\right)\right) \text { is obtained }\left(. \mathrm{m}^{-2}\right) \\
\text { (different from the maximum tested density during experiment). This parameter is used for } \mathrm{n} \rightarrow \infty \\
\text { in mathematical functions maxM( }\left(\mathrm{U}^{*}, \mathrm{~N}\right) \text {. }\end{array}$ \\
\hline $\mathrm{W}$ & Sediment moisture content (\%) \\
\hline \multicolumn{2}{|c|}{ Derived variables } \\
\hline Q & $\begin{array}{l}\left.\text { Standardized maxM( } \mathrm{u}^{*}, \mathrm{n}\right) \text { values for a current velocity }(\mathrm{u}) \text { and an animal density }(\mathrm{n}) \text { by sigmoid } \\
\text { maximum values maxM(U*, n) (no units) }\end{array}$ \\
\hline $\operatorname{maxM}\left(U^{*}, \mathbf{n}\right)$ & $\begin{array}{l}\text { Asymptotic concentration of mass of eroded sediment } \mathrm{M} \text { as a function of current velocity and } H \text {. } \\
\text { ulvae density } \mathrm{n} \text { (represents the plateau obtained for each increment in one experiment where an } \\
\text { animal density was tested) }\end{array}$ \\
\hline \multicolumn{2}{|c|}{ Constants and parameters } \\
\hline $\mathrm{u}_{\mathrm{c}}{ }^{*}$ & Critical threshold shear velocity for sediment erosion $\left(\mathrm{m} . \mathrm{s}^{-1}\right)$ \\
\hline$\alpha$ & Asymmetry parameter of the Weibull function Q \\
\hline$\beta$ & Increasing rate of the Weibull function Q. \\
\hline$v$ & H. ulvae density, density dependance parameter $\left(\mathrm{m}^{2}\right)$ \\
\hline $\max M\left(U^{*}, 0\right)$ & $\begin{array}{l}\text { Asymptotic concentration or mass of eroded } \mathrm{M} \text { when } \mathrm{u}^{*} \rightarrow \infty\left(=\mathrm{U}^{*}\right) \text { and for zero } H \text {.ulvae density } \\
(\mathrm{n}=0)\left(\mathrm{g} \cdot \mathrm{m}^{-2}\right) \text {. }\end{array}$ \\
\hline $\max M\left(U^{*}, \mathbf{N}\right)$ & $\begin{array}{l}\text { Asymptotic concentration or mass of eroded sediment }\left(\mathrm{g} \cdot \mathrm{m}^{-2}\right) \text { when } \mathrm{u}^{*} \rightarrow \infty\left(=\mathrm{U}^{*}\right) \text { and for } H \text {. } \\
\text { ulvae density } \mathrm{n} \rightarrow \infty(=\mathrm{N}) \text {. }\end{array}$ \\
\hline $\mathbf{k}$ & Instantaneous erosion rate parameter $\left(\mathrm{s}^{-1}\right)$ \\
\hline$\gamma$ & $\begin{array}{l}\text { Exponential parameter describing dependence of the sigmoid maximum value maxM(U*, n) on } \\
\text { the moisture content estimated at the sediment/water interface (no units). }\end{array}$ \\
\hline
\end{tabular}


Table 3 :

\begin{tabular}{|c|c|c|}
\hline Parameter & Average value (Runnel) & Average value (Ridge) \\
\hline \multicolumn{3}{|c|}{ “2×6 parameter model” for independent “Runnel/Ridge” models (identical to Willows’ model). } \\
\hline$\alpha$ & $1.28 \pm 0.18$ & $1.56 \pm 0.014$ \\
\hline$\beta\left(\mathrm{m} . \mathrm{s}^{-1}\right)$ & $4.45 \pm 1.04$ & $2.12 \pm 0.01$ \\
\hline$k\left(\min ^{-1}\right)$ & $0.56 \pm 0.13$ & $0.26 \pm 0.01$ \\
\hline $\max M\left(U^{*}, O\right)\left(\mathrm{g} \cdot \mathrm{m}^{-2}\right)$ & $15.80 \pm 4.31$ & $0.97 \pm 0.04$ \\
\hline $\max M\left(U^{*}, N\right)\left(\mathrm{g} \cdot \mathrm{m}^{-2}\right)$ & $59.99 \pm 7.45$ & $6.13 \pm 0.03$ \\
\hline$v\left(\mathrm{~m}^{2}\right.$ per Hydrobia $)$ & $0.08 \times 10^{-4} \pm 0.01 .10^{-4}$ & $1.00 \times 10^{-4} \pm 0.01 .10^{-4}$ \\
\hline \multicolumn{3}{|c|}{ Single “8-parameter model” model including “Moisture content” factor. } \\
\hline$\alpha$ & 1.28 & \\
\hline$\beta\left(\mathrm{m} . \mathrm{s}^{-1}\right)$ & 3.89 & \\
\hline$k\left(\min ^{-1}\right)$ & 0.25 & \\
\hline $\max M\left(U^{*}, O\right)\left(\mathrm{g} \cdot \mathrm{m}^{-2}\right)$ & $15.96 \pm 2.19$ & $0.97 \pm 0.30$ \\
\hline $\max M\left(U^{*}, N\right)\left(\mathrm{g} \cdot \mathrm{m}^{-2}\right)$ & 75.0 & .10 \\
\hline$v\left(\mathrm{~m}^{2}\right.$ per Hydrobia $)$ & $2.40 \times 10^{-8}$ & $22 \times 10^{-8}$ \\
\hline$\gamma$ & $0.29 \times 10^{-1}$ & $.01 \times 10^{-1}$ \\
\hline \multicolumn{3}{|c|}{ Single "9-parameter model" including "Moisture content" factor and with differentiation of $\beta$ for each cas } \\
\hline$\alpha$ & 1.37 & \\
\hline$\beta\left(\mathrm{m} . \mathrm{s}^{-1}\right)$ & $4.41 \pm 0.78$ & $2.12 \pm 0.61$ \\
\hline$k\left(\min ^{-1}\right)$ & 0.2 & \\
\hline $\max M\left(U^{*}, O\right)\left(\mathrm{g} \cdot \mathrm{m}^{-2}\right)$ & $15.96 \pm 2.19$ & $0.97 \pm 0.32$ \\
\hline $\max M\left(U^{*}, N\right)\left(\mathrm{g} \cdot \mathrm{m}^{-2}\right)$ & 75.0 & .70 \\
\hline$v\left(\mathrm{~m}^{2}\right.$ per Hydrobia $)$ & $2.40 \times 10^{-8}$ & $22 \times 10^{-8}$ \\
\hline$\gamma$ & $0.29 \times 10^{-1}$ & $.01 \times 10^{-1}$ \\
\hline Model & Coefficient of determination $\mathbf{r}^{2}$ (runnel) & Coefficient of determination $r^{2}$ (ridge) \\
\hline \multirow[t]{2}{*}{ “ $2 \times 6$ parameter model” } & $\max M\left(U^{*}, n\right): r^{2}=0.744$ & $\max M\left(U^{*}, n\right): r^{2}=0.869$ \\
\hline & $M: r^{2}=0.883$ & $M: r^{2}=0.904$ \\
\hline \multirow[t]{2}{*}{ “8-parameter model” } & $\max M\left(U^{*}, n\right): r^{2}=0.867$ & $\max M\left(U^{*}, n\right): r^{2}=0.827$ \\
\hline & $M: r^{2}=0.896$ & $M: r^{2}=0.344$ \\
\hline \multirow[t]{2}{*}{ “9-parameter model” } & $\max M\left(U^{*}, n\right): r^{2}=0.867$ & $\max M\left(U^{*}, n\right): r^{2}=0.827$ \\
\hline & $M: r^{2}=0.912$ & $M: r^{2}=0.830$ \\
\hline
\end{tabular}





\section{Figure captions:}

Fig. 1: Shore-normal ridge and runnel system developed on the Montportail-Brouage mudflat in the Marennes-Oléron Bay at mid-tide level. Note the incoming tide in the back front (a). Depth profiles of sediment wet bulk density from cores taken on ridges (b) and in runnels (c) of the mudflat.

Fig. 2: Depth profiles of sediment concentration for pre-equilibrated trays of control sediments used in the ridge (a) and runnel (b) flume experiments. Note the more homogeneous profile of the prepared ridge sediments compared to the runnel sediments $(n=3$ and $n=6$, respectively).

Fig. 3: Depth profiles of microalgal pigments for pre-equilibrated control sediments used in the ridge (a) and runnel (b) experiments ( $n=3$ and $n=6$, respectively). The phaeopigments (square and dashed line) and the chl $a$ (triangle and full line) are plotted per gram of dry sediment.

Fig. 4: Time series of the sediment mass eroded $\left(\mathrm{M}\right.$ in $\left.\mathrm{g} \cdot \mathrm{m}^{-2}\right)$ in the flume in response to stepwise increments in bed shear stress(0 to 1.6 Pa), as a function Hydrobia ulvae population density $\left(0,1,000,5,000,10,000\right.$ and 50,000 snails. $\left.\mathrm{m}^{-2}\right)$ for experimental test beds of ridge (a) and runnel (b) sediments. Two experiments were completed at each snail density (replicate numbers).

Fig. 5: Relationship between the ratio of the (total photosynthetic pigment concentrations) to (sediment mass eroded) and Hydrobia ulvae density in flume experiments for ridge-type sediments (diamonds) and runnel-type sediments (square). Each ratio value (in 
$\mu \mathrm{g}_{\text {pigment. }}$. $_{\text {sediment }}{ }^{-1}$ ) was calculated as the slope of the linear regression between total photosynthetic pigment concentration and the sediment mass eroded ( $\mathrm{n}=24$ measurements).

Fig. 6: Measured time series for the ratio of phaeopigment to chl $a$ concentrations in suspended material as a function of Hydrobia ulvae density (0 (circles), 1,000 (squares), 5,000 (triangle), 10,000 (crosses), 50,000 (diamonds) snails. $\mathrm{m}^{-2}$ ) for ridge-type (a) and runnel-type (b) sediments.

Fig. 7: Relationship between phaeopigment and chl $a$ concentrations for the data from ridge (a) and runnel (b and c) experiments. Data for runnel sediments were discriminated according to the chl $a$ concentration within the interval $0<\mathrm{Chl} a<0.05 \mu \mathrm{g}_{\text {pigment. }} \mathrm{l}^{-1}$ (b) and over 0.05 $\mu \mathrm{g}_{\text {pigment. }} \mathrm{l}^{-1}(\mathrm{c})$.

Fig. 8: Theoretical representation of the kinetics of eroded sediment mass, $M$, (a) within one bed shear stress increment; (b) the asymptotic concentration $\max M\left(u^{*}, n\right)$ as a function of friction velocity; and (c) the sigmoid maximum maxM(U*, n) as a function of Hydrobia ulvae density $n$.

Fig. 9: Sigmoid maximum of $\max M\left(U^{*}, n\right)$ as a function of Hydrobia ulvae density for both “2×6 parameter model” and "8-parameter model”: results minimised from the first step of parameterisation for ridge- and runnel- (diamond) type sediments. Computed results of the “ $2 \times 6$ parameter model” for the ridge sediments (dashed line; $r^{2}=0.86$ ) and runnel conditions (full line; $\mathrm{r}^{2}=0.74$ ); computed results for the "8-parameter model" for ridge conditions $\left(r^{2}=0.87\right)$ and runnel sediments $\left(r^{2}=0.90\right)$. 
Fig. 10: Time series of experimental eroded sediment mass $M$ (from Figure 4), compared to computed results with the " $2 \times 6$ parameter model” (wide smooth lines) for the five Hydrobia densities (gradation of grey colours), for ridge (a) and runnel (b) conditions.

Fig. 11: Sigmoid maximum $\operatorname{maxM}\left(\mathrm{U}^{*}, \mathrm{n}\right)$ as a function of the moisture content at the sediment water interface of both runnel and ridge sediments. Results are presented according to Hydrobia ulvae density: 1,000 (diamond); 5,000 (square); 10,000 (triangle) and 50,000 (cross) snails.m ${ }^{-2}$. Adjusted equations are: $\mathrm{y}=5.10^{-15} \cdot \mathrm{x}^{6.31}\left(\mathrm{r}^{2}=0.995\right), \mathrm{y}=2.10^{-11} \cdot \mathrm{x}^{4.96}\left(\mathrm{r}^{2}=0.998\right)$, $y=1.10^{-10} \cdot x^{4.72}\left(r^{2}=0.941\right)$ and $y=2.10^{-10} \cdot x^{4.75}\left(r^{2}=0.980\right)$, respectively.

Fig. 12: Time series of experimental suspended sediment concentrations compared to "8parameter model” computed results (wide smooth lines), including the influence of the moisture content at the water-sediment interface for the 5 Hydrobia ulvae densities (gradation of grey colours), for the ridge (a) and runnel (b) experimental conditions.

Fig. 13: Comparison between the computed sigmoid maximum $\max M\left(U^{*}, n\right)$ as a function of the animal density estimated by the " $2 \times 6$ parameter model" for the model proposed by Willows et al. (1998) describing Macoma balthica bioturbation activities (dotted line), and the corresponding description for Hydrobia ulvae bioturbation activity on ridges (full line) and runnels (dashed line).

Table 1: Sediment moisture contents and sediment concentrations for each experiment. Measured values from the top centimetre of sediment and estimated values at the sedimentwater interface (description of estimation method in text). 
Table 2: Notation used for the model equation system. Bold parameters were estimated by minimisation.

Table 3: Estimates of model parameters and their standard errors. 

Figure 1

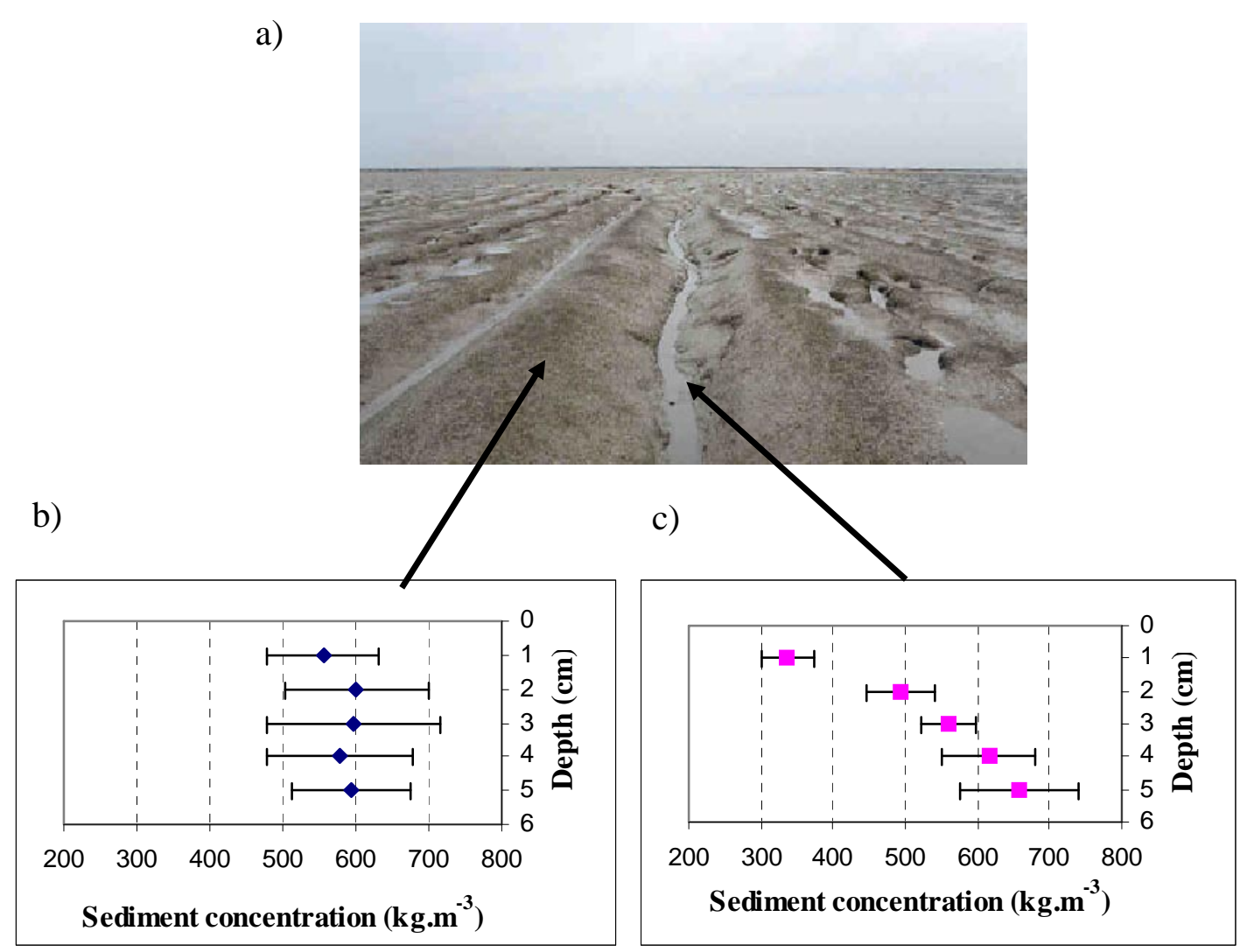


Figure 2

a)

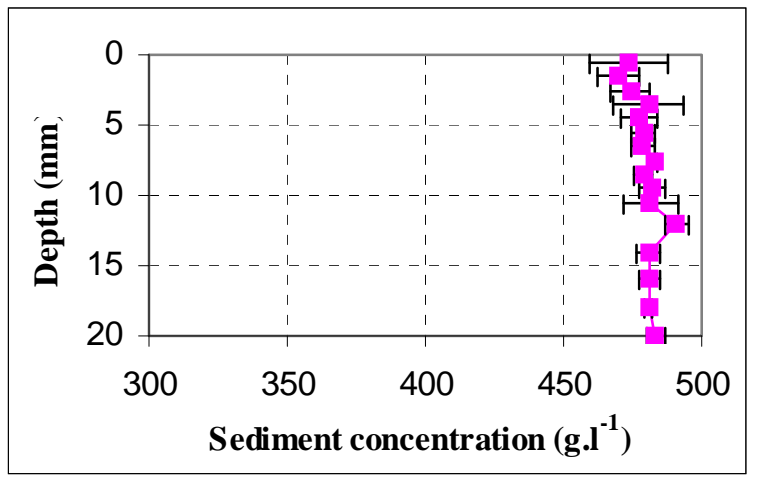

b)

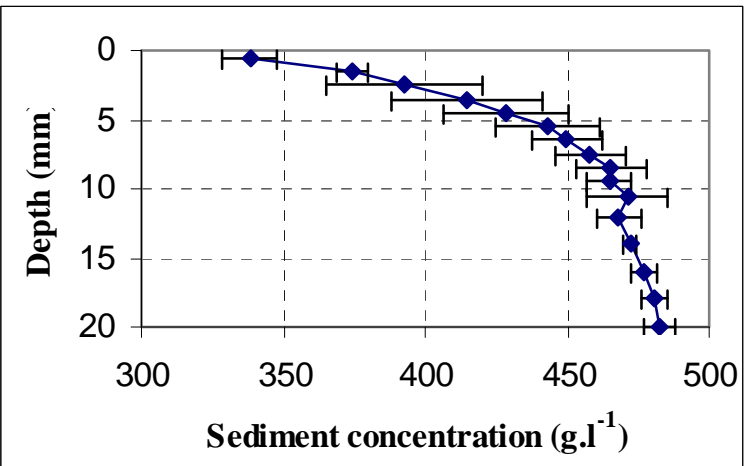


Figure 3

a)

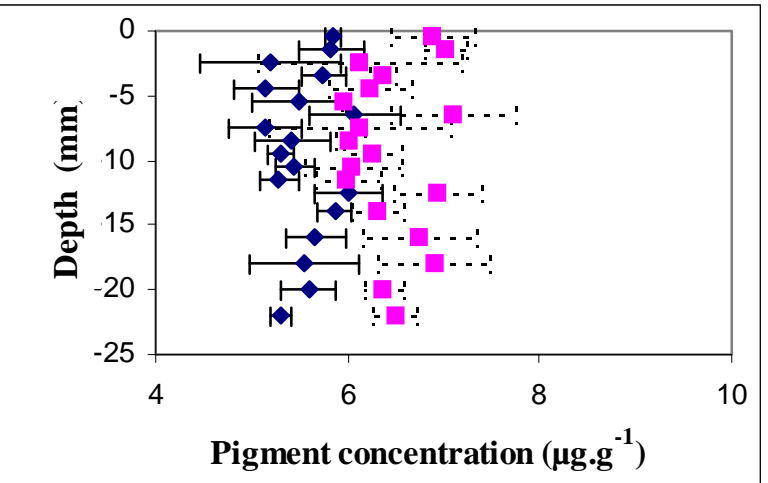

b)

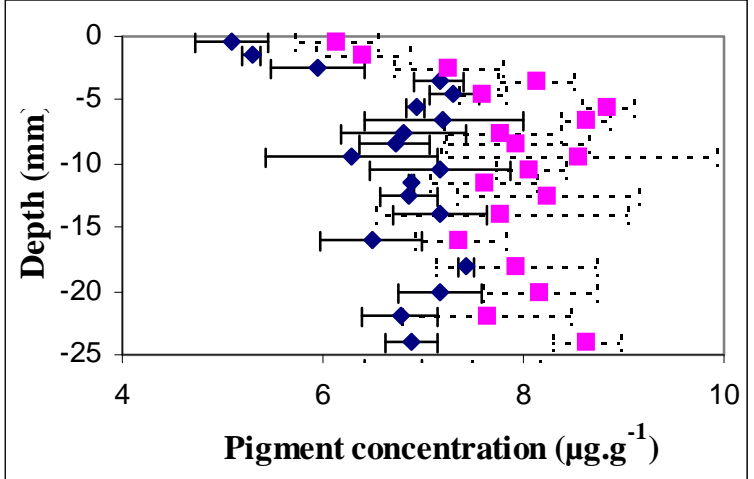


Figure 4

a)

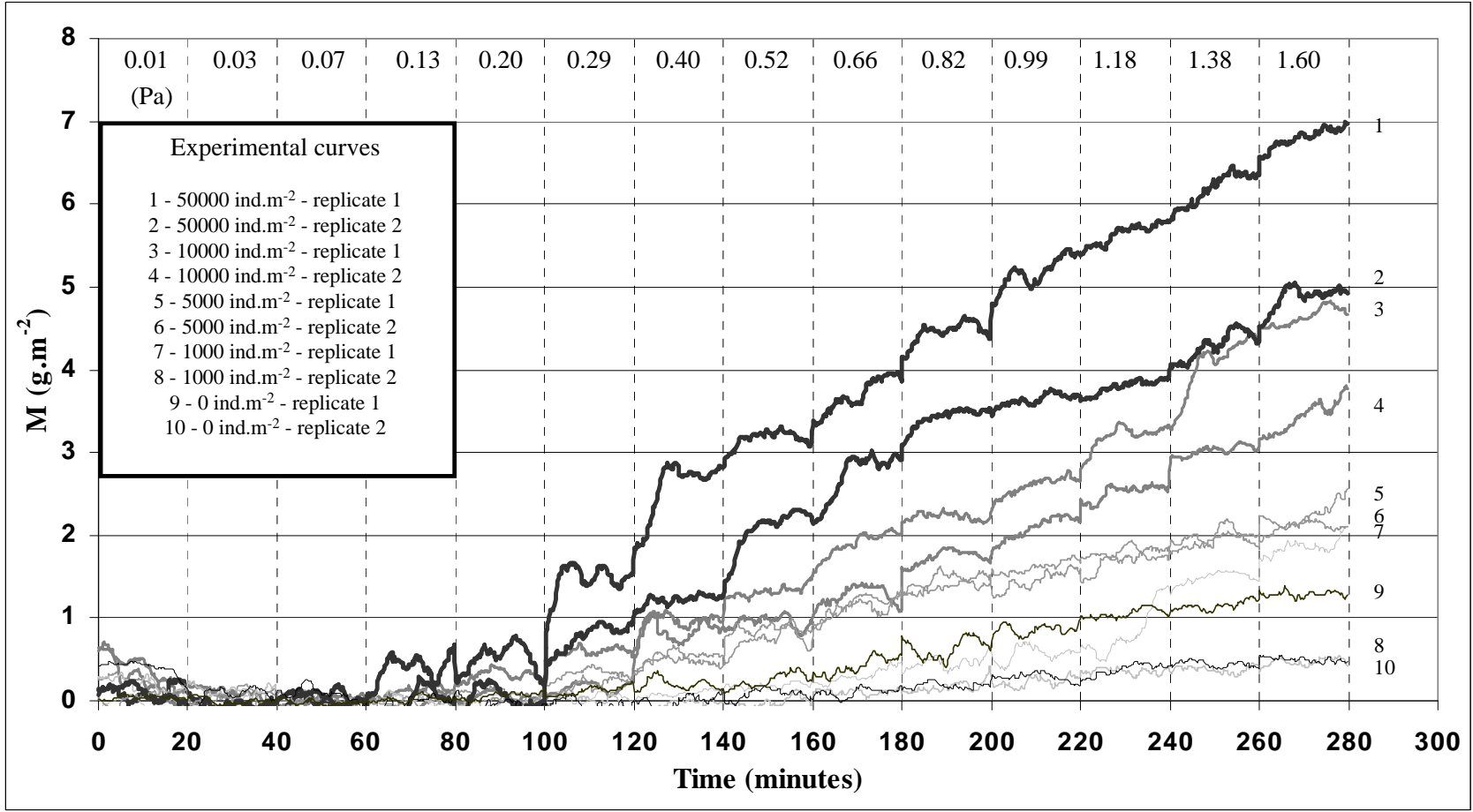

b)

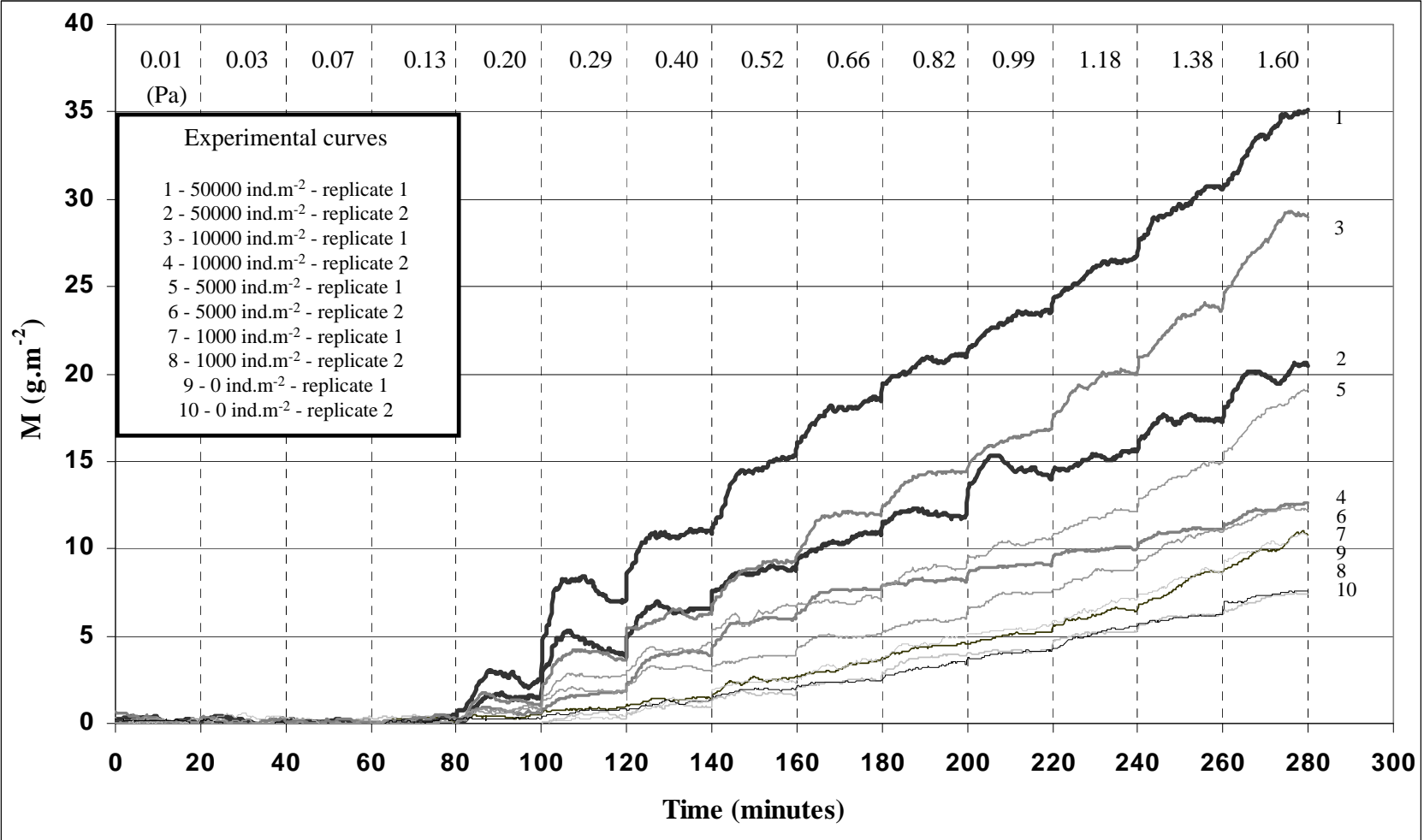


Figure 5

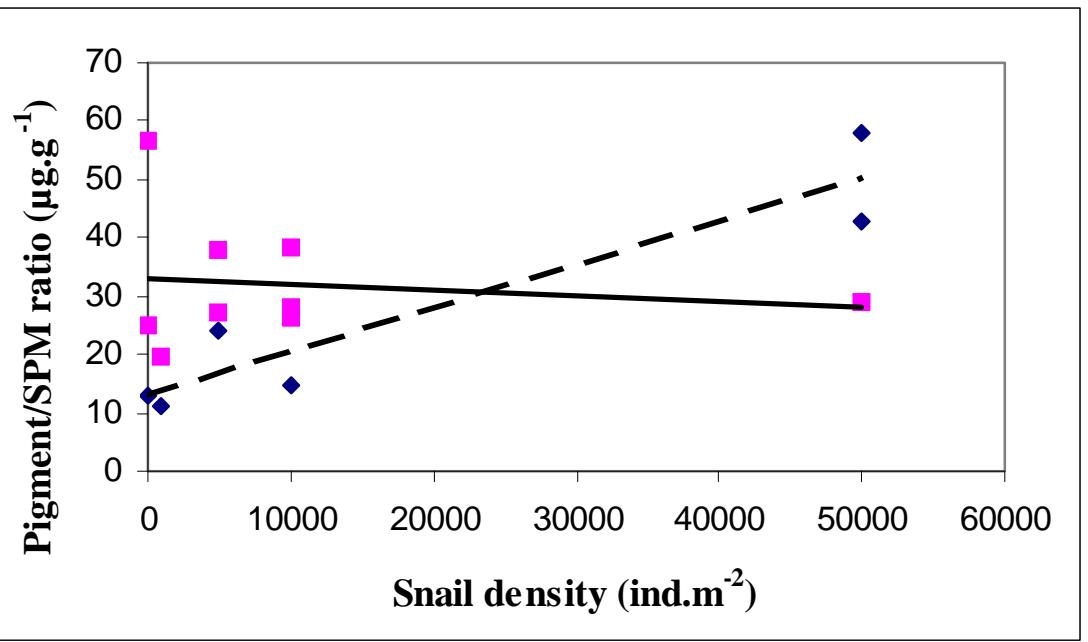


Figure 6

a)

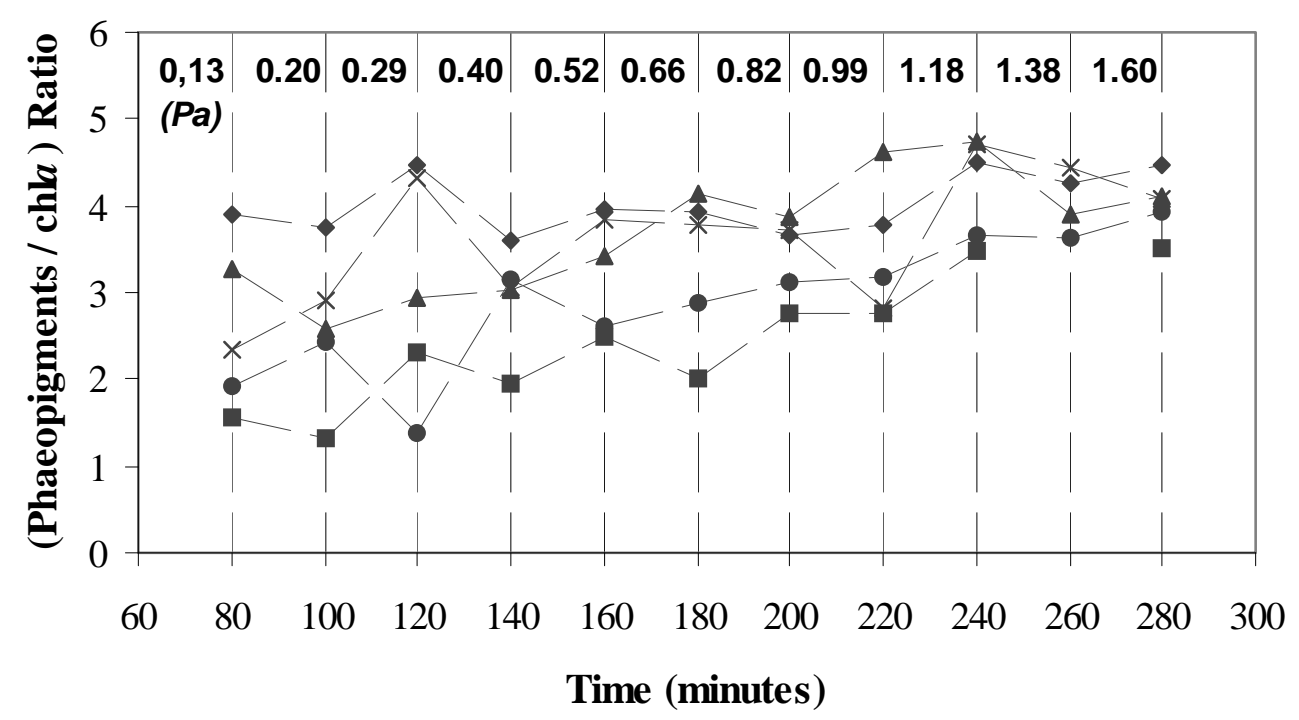

b)

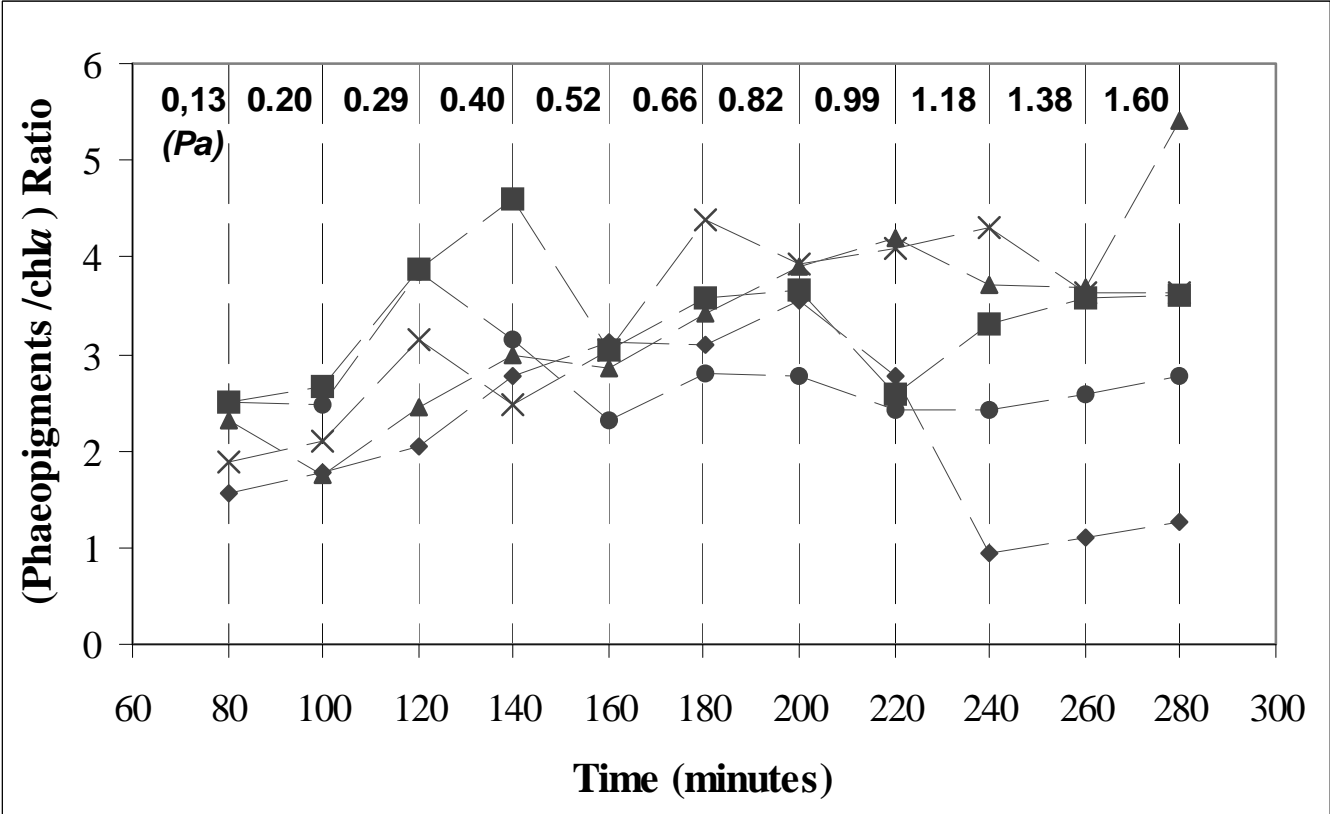


Figure 7

a)

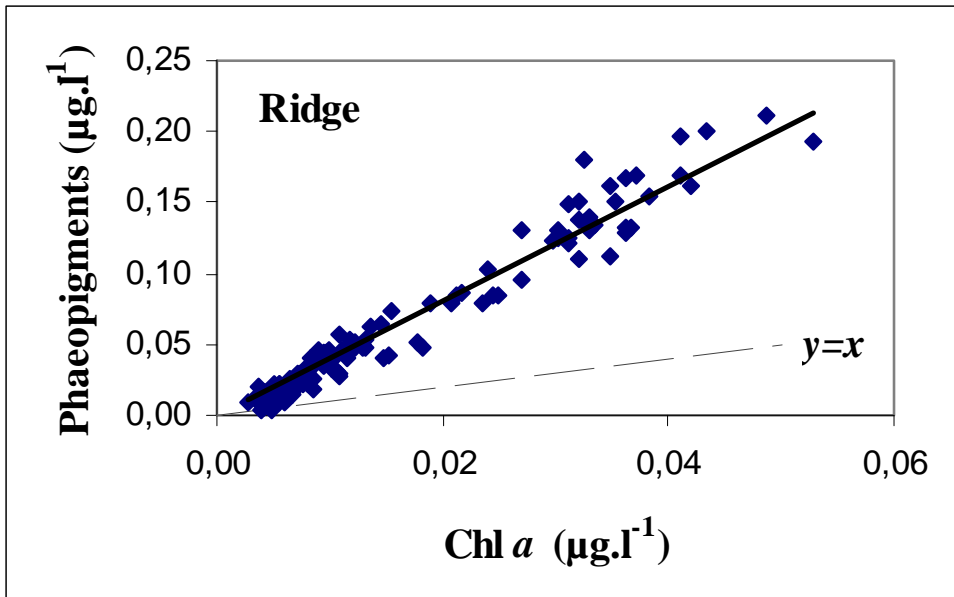

b)

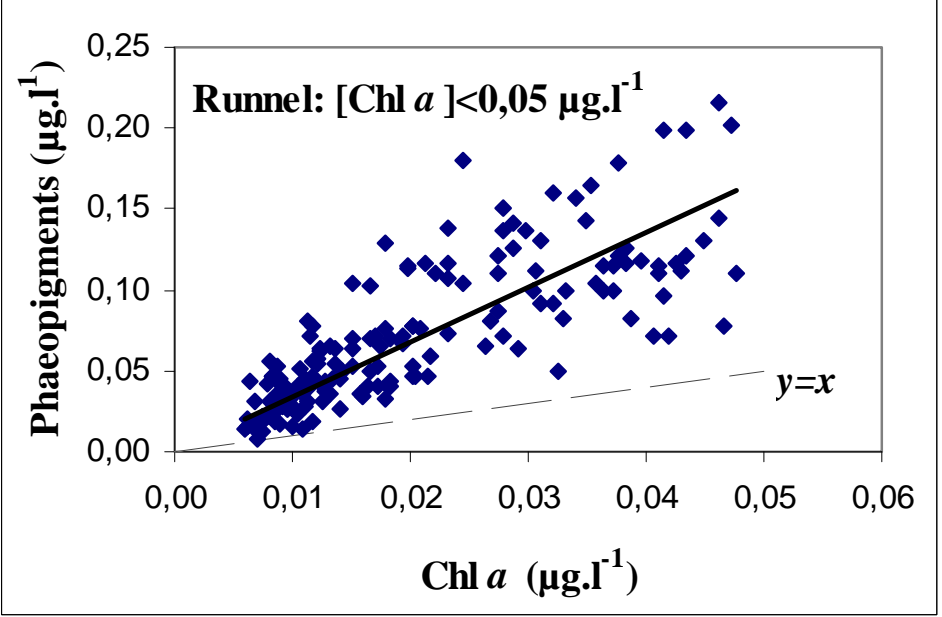

c)

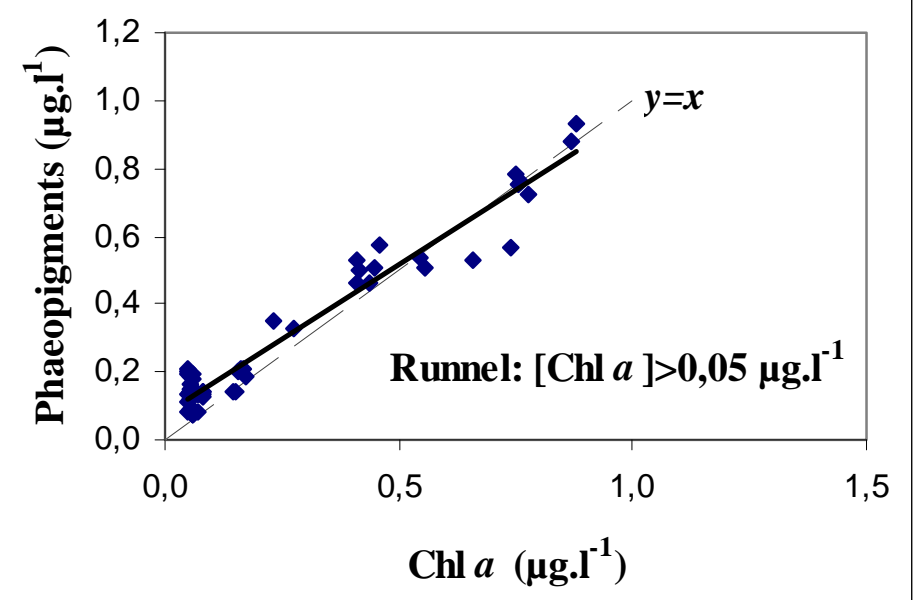


Figure 8

a)

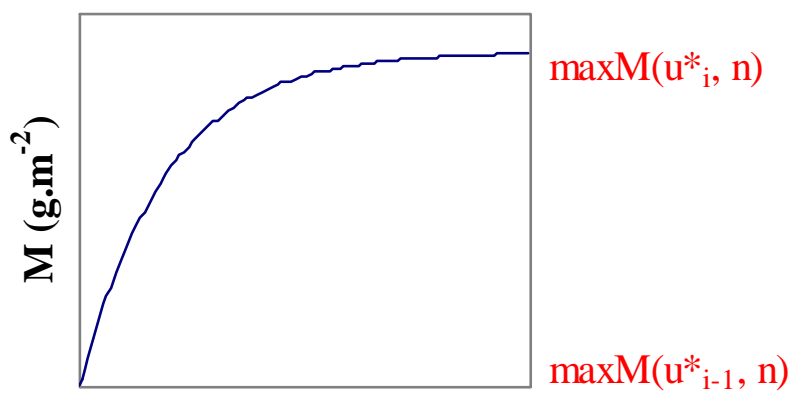

Time (minutes)

b)

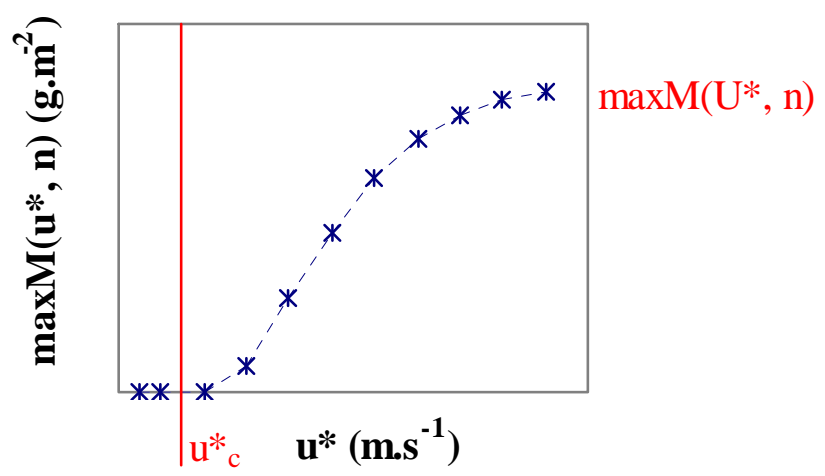

c)

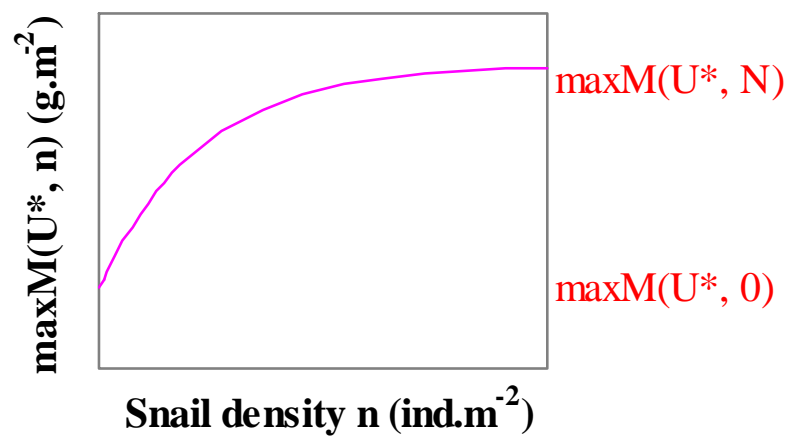


Figure 9

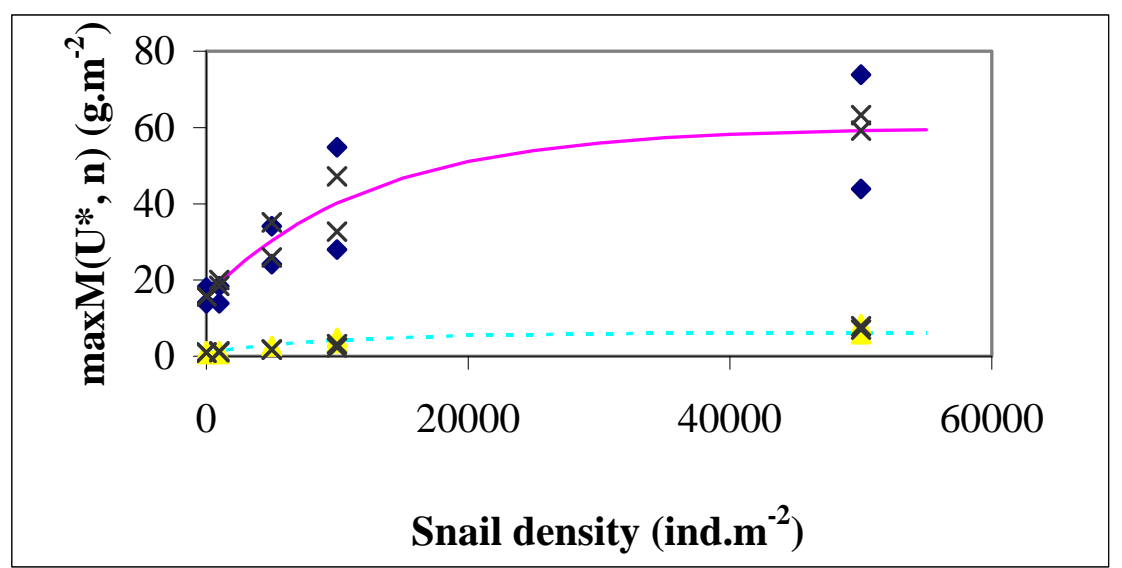


Figure 10

a)

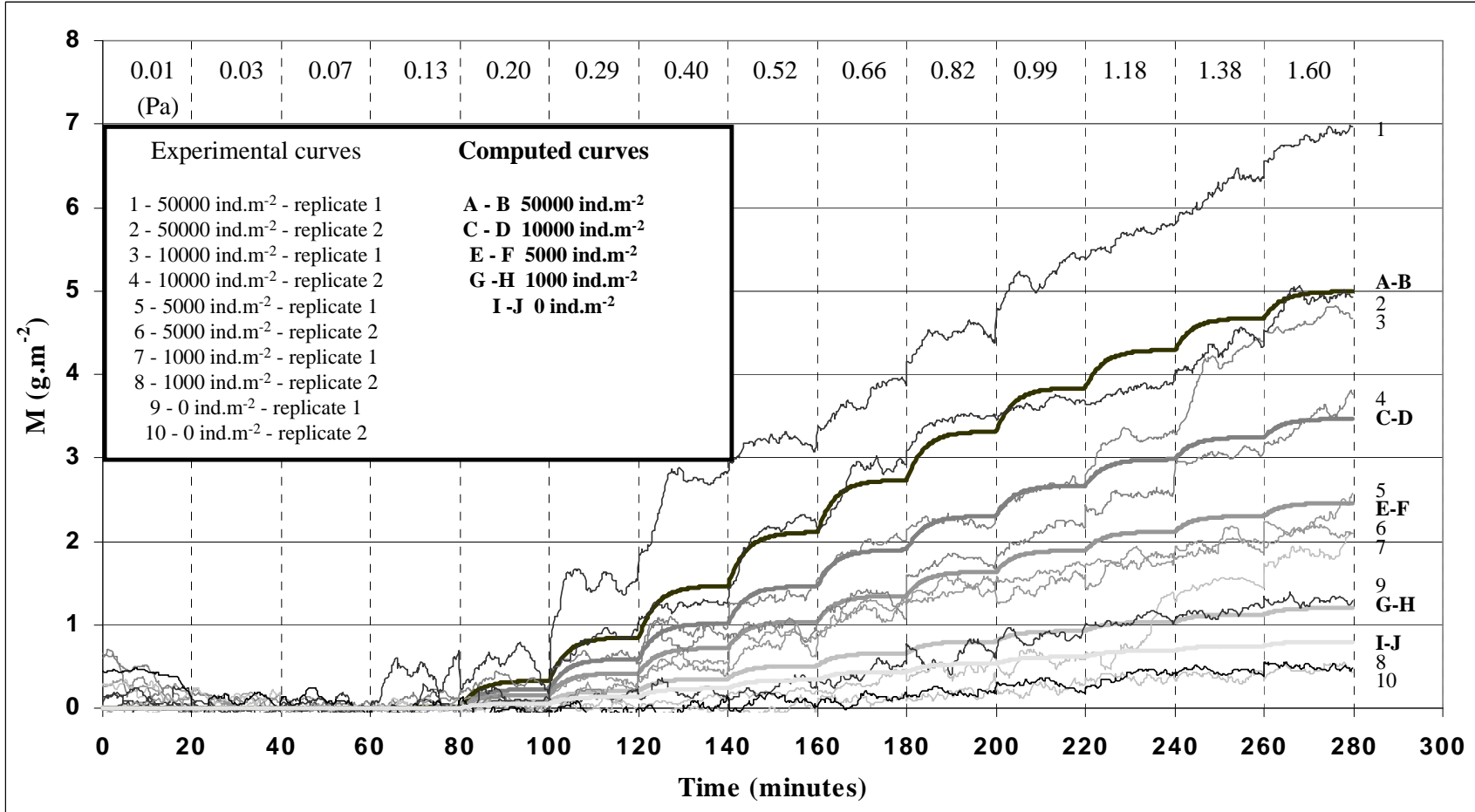

b)

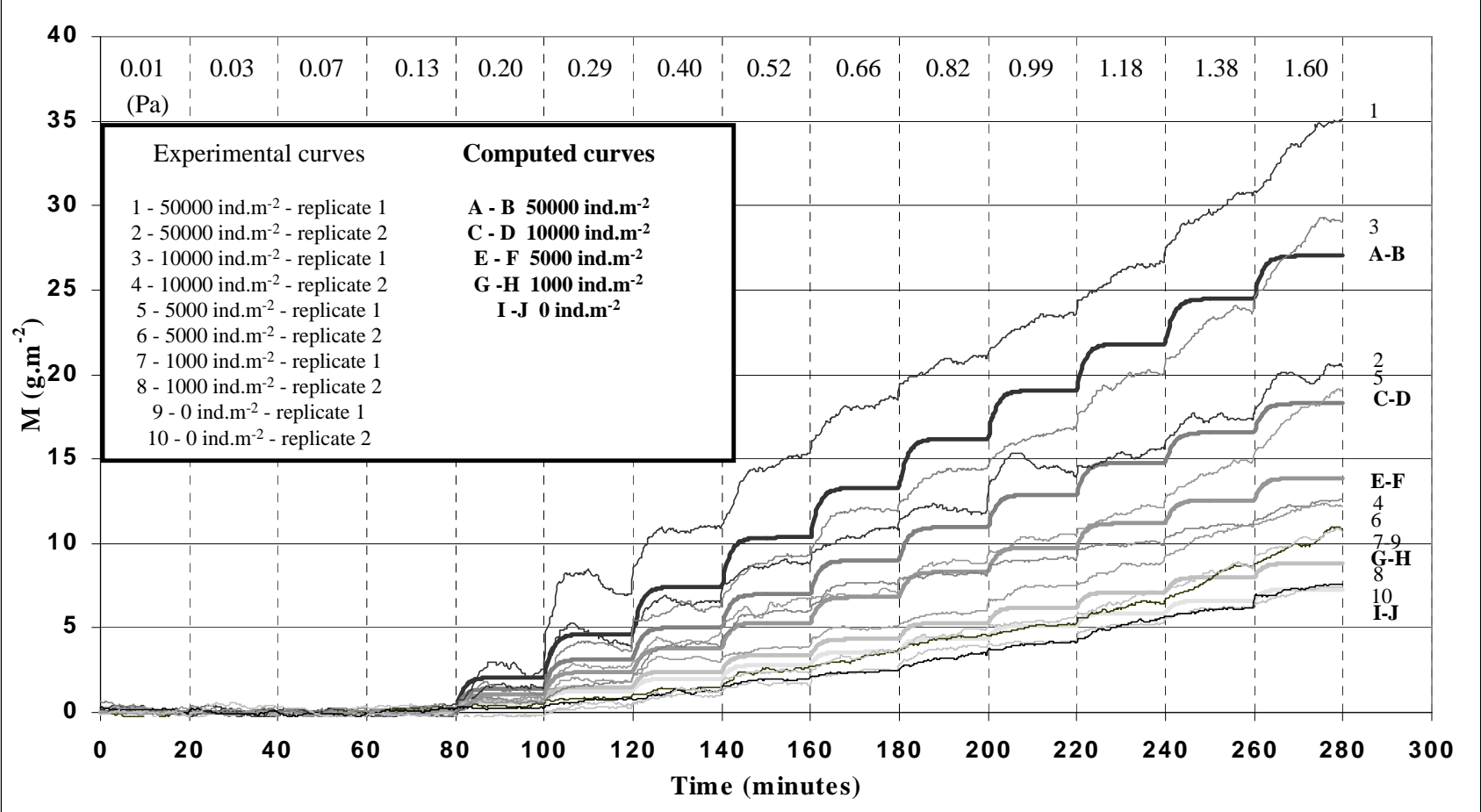


Figure 11

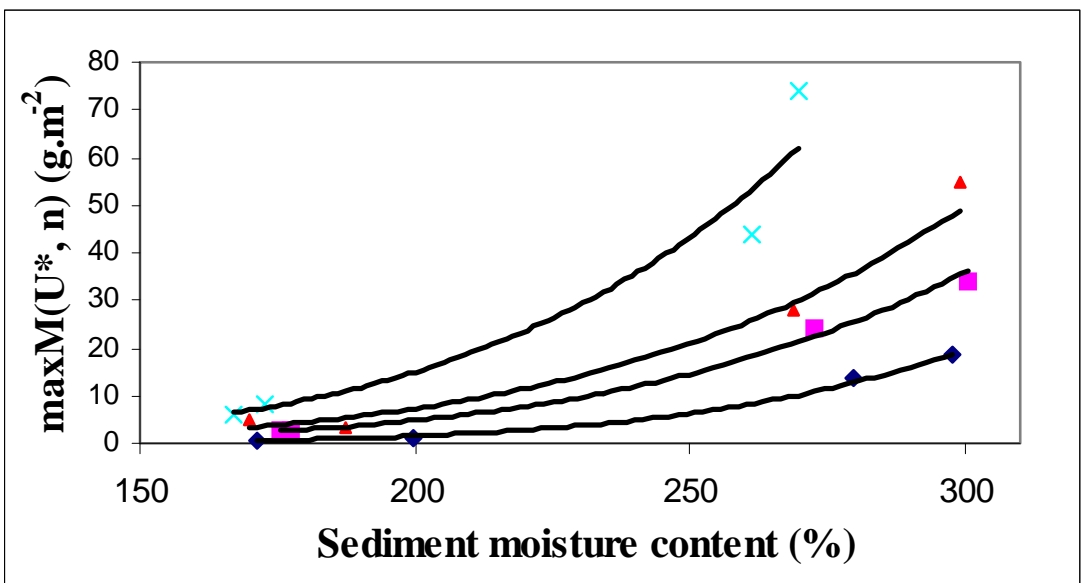


Figure 12

a)

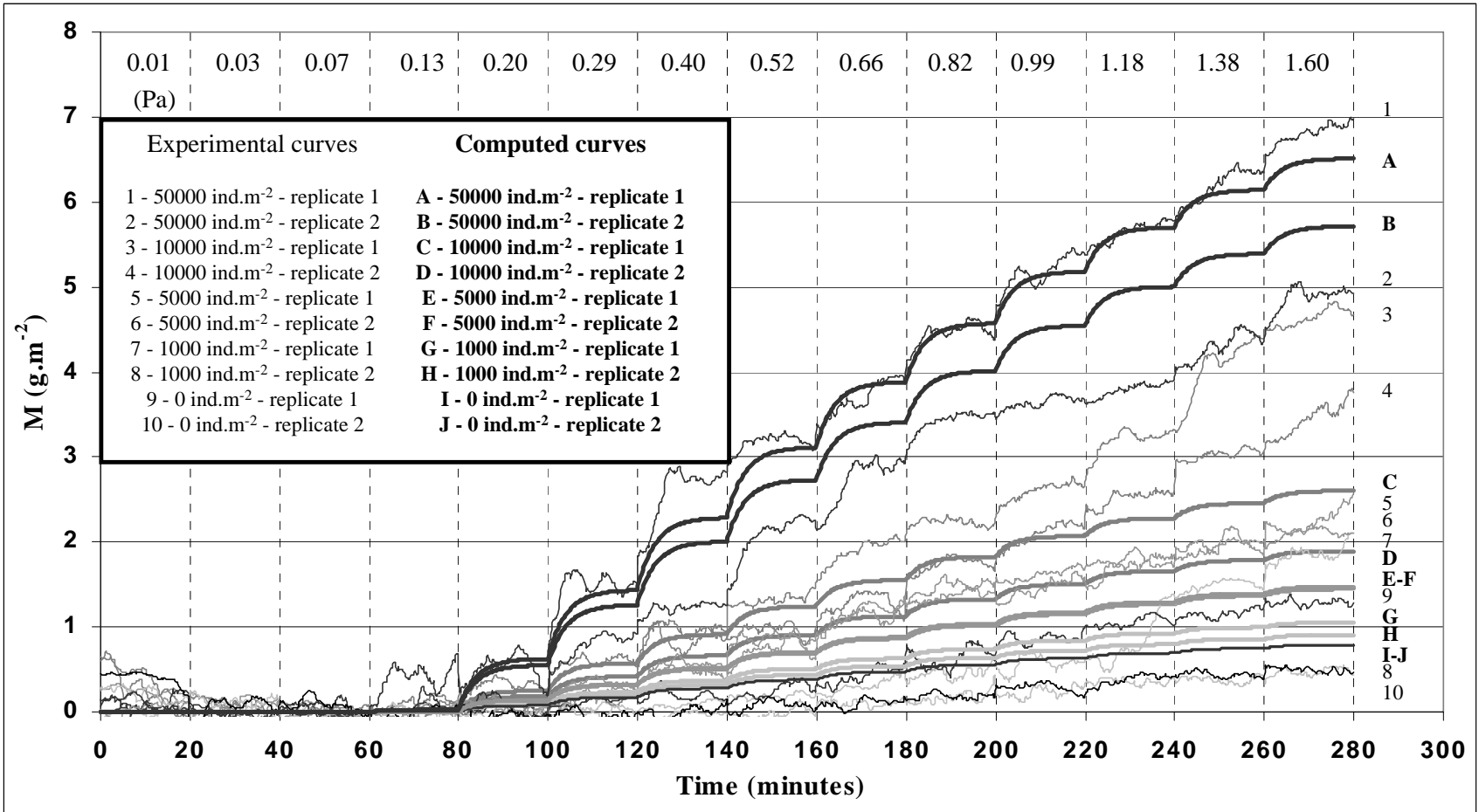

b)

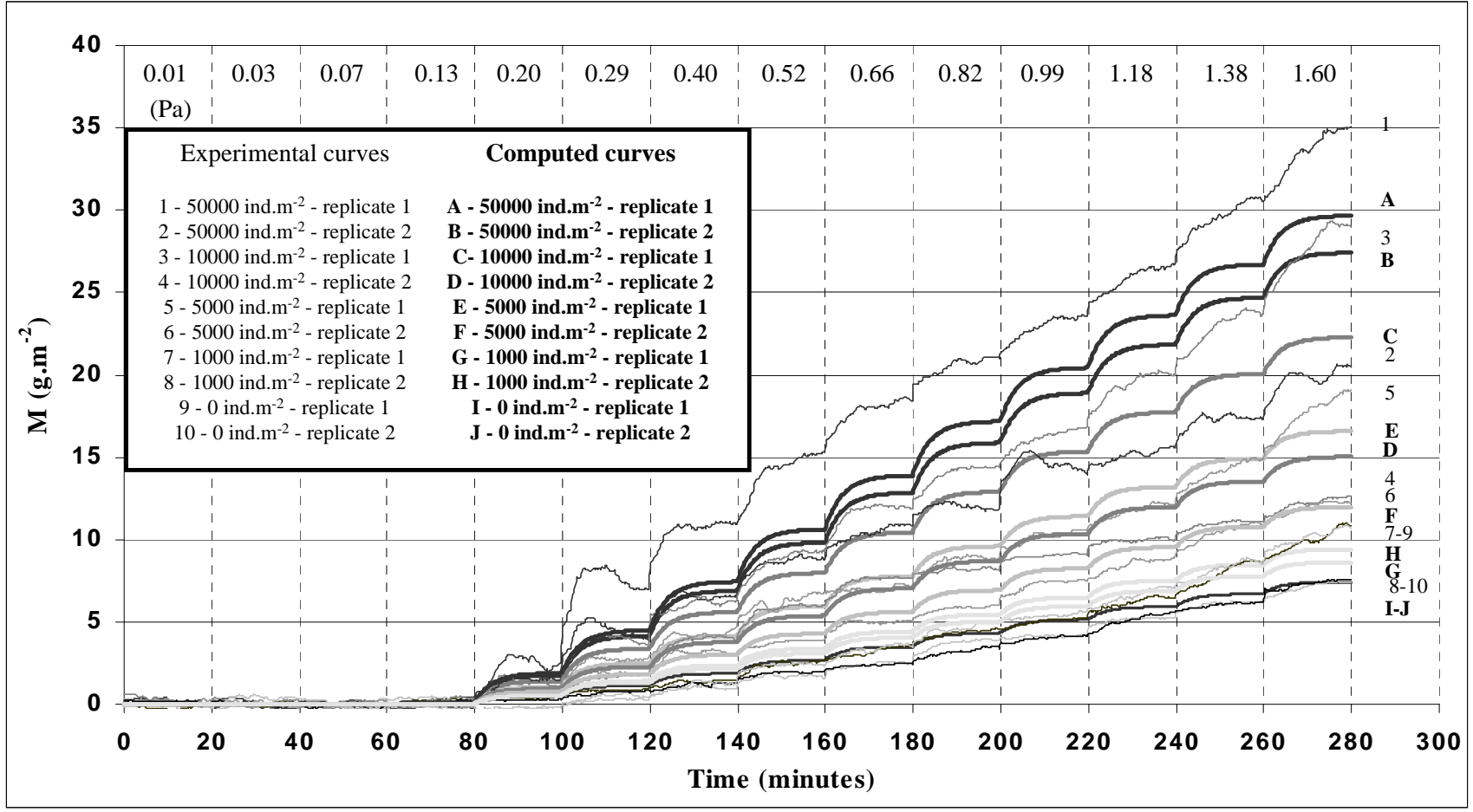


Figure 13

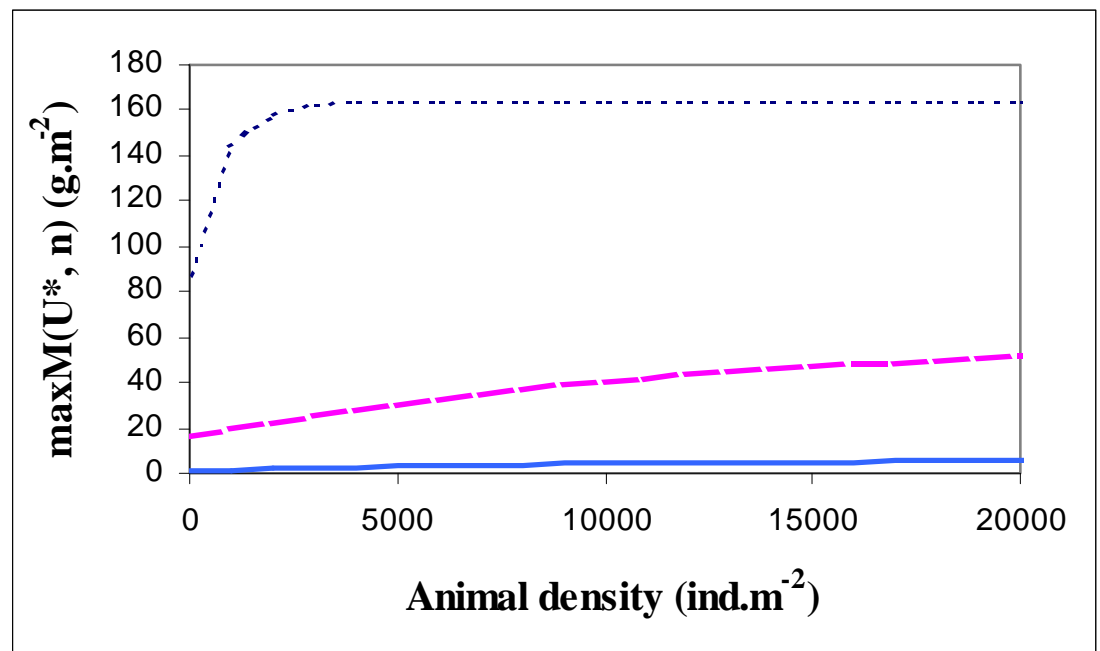


Table 1 :

\begin{tabular}{|c|c|c|c|c|c|}
\hline & $\begin{array}{l}\text { Hydrobia ulvae } \\
\text { density }\end{array}$ & $\begin{array}{l}\text { Measured sediment } \\
\text { concentration at the } \\
\text { uppermost cm }\left(\mathrm{kg} \cdot \mathrm{m}^{-3}\right)\end{array}$ & $\begin{array}{l}\text { Estimated sediment } \\
\text { concentration at the } \\
\text { interface }\left(\mathrm{kg} \cdot \mathrm{m}^{-3}\right)\end{array}$ & $\begin{array}{l}\text { Measured moisture } \\
\text { content at the } \\
\text { uppermost cm (\%) }\end{array}$ & $\begin{array}{l}\text { Estimated moisture } \\
\text { content at the } \\
\text { interface (\%) }\end{array}$ \\
\hline \multicolumn{6}{|l|}{$\begin{array}{l}\text { runnel } \\
\text { sediments }\end{array}$} \\
\hline & 0 & 423 & 339 & 198 & 258 \\
\hline & 0 & 423 & 339 & 198 & 258 \\
\hline & 1000 & 394 & 315 & 216 & 280 \\
\hline & 1000 & 373 & 298 & 230 & 298 \\
\hline & 5000 & 403 & 322 & 210 & 273 \\
\hline & 5000 & 370 & 296 & 233 & 301 \\
\hline & 10000 & 408 & 326 & 207 & 269 \\
\hline & 10000 & 371 & 297 & 232 & 299 \\
\hline & 50000 & 407 & 325 & 208 & 270 \\
\hline & 50000 & 418 & 334 & 201 & 261 \\
\hline \multicolumn{6}{|l|}{$\begin{array}{l}\text { "Ridge" } \\
\text { experiments }\end{array}$} \\
\hline & 0 & 485 & 485 & 169 & 169 \\
\hline & 0 & 482 & 482 & 170 & 170 \\
\hline & 1000 & 422 & 422 & 200 & 200 \\
\hline & 1000 & 478 & 478 & 171 & 171 \\
\hline & 5000 & 468 & 468 & 176 & 176 \\
\hline & 5000 & 465 & 465 & 177 & 177 \\
\hline & 10000 & 444 & 444 & 187 & 187 \\
\hline & 10000 & 482 & 482 & 170 & 170 \\
\hline & 50000 & 475 & 475 & 173 & 173 \\
\hline & 50000 & 488 & 488 & 167 & 167 \\
\hline
\end{tabular}




\section{Table 2 :}

\begin{tabular}{|c|c|}
\hline \multicolumn{2}{|l|}{ Variables } \\
\hline$\overline{\mathrm{u}}$ & Free Current velocity at height $=4 \mathrm{~cm}$ above the bottom $\left(\mathrm{m} . \mathrm{s}^{-1}\right)$ \\
\hline $\mathrm{u}^{*}$ & Friction velocity $\left(\mathrm{m} . \mathrm{s}^{-1}\right)$ \\
\hline $\mathrm{U}^{*}$ & $\begin{array}{l}\text { Friction velocity for which } M \text { reached its asymptotic maximum value }\left(\operatorname{maxM}\left(\mathrm{U}^{*}, \mathrm{n}\right)\right)(\text { different } \\
\text { from the maximum shear velocity obtained during experiments). This parameter is used to mean } \\
\text { that } \mathrm{u}^{*} \rightarrow \infty \text { in mathematical functions } \operatorname{maxM}\left(\mathrm{U}^{*}, \mathrm{n}\right) \text {. }\end{array}$ \\
\hline M & Sediment mass eroded converted from direct measured turbidity $\left(\mathrm{g} \cdot \mathrm{l}^{-1}\right)$ in the flume $\left(\mathrm{g} \cdot \mathrm{m}^{-2}\right)$ \\
\hline $\mathrm{n}$ & Hydrobia ulvae numerical density $\left(. \mathrm{m}^{-2}\right)$ \\
\hline $\mathrm{N}$ & $\begin{array}{l}\text { H. ulvae density for which the sigmoid maximum value }\left(\operatorname{maxM}\left(\mathrm{U}^{*}, \mathrm{~N}\right)\right) \text { is obtained }\left(. \mathrm{m}^{-2}\right) \\
\text { (different from the maximum tested density during experiment). This parameter is used to mean } \\
\text { that } \mathrm{n} \rightarrow \infty \text { in mathematical functions } \operatorname{maxM}\left(\mathrm{U}^{*}, \mathrm{~N}\right) \text {. }\end{array}$ \\
\hline W & Sediment moisture content $(\%)$ \\
\hline \multicolumn{2}{|c|}{ Derived variables } \\
\hline Q & $\begin{array}{l}\left.\text { Standardized maxM( } \mathrm{u}^{*}, \mathrm{n}\right) \text { values for a current velocity }(\mathrm{u}) \text { and an animal density }(\mathrm{n}) \text { by sigmoid } \\
\text { maximum values maxM(U*, n) (no unit) }\end{array}$ \\
\hline $\operatorname{maxM}\left(U^{*}, \mathbf{n}\right)$ & $\begin{array}{l}\text { Asymtotic concentration of mass of eroded sediment } \mathrm{M} \text { as a function of current velocity and } H \text {. } \\
\text { ulvae density } \mathrm{n} \text { (represents the plateau obtained for every increment during one experiment } \\
\text { where an animal density was tested) }\end{array}$ \\
\hline \multicolumn{2}{|c|}{ Constants and parameters } \\
\hline $\mathrm{u}_{\mathrm{c}}{ }^{*}$ & Critical threshold shear velocity for sediment erosion $\left(\mathrm{m} . \mathrm{s}^{-1}\right)$ \\
\hline$\alpha$ & Asymmetry parameter of the Weibull function Q \\
\hline$\beta$ & Increasing rate of the Weibull function $\mathrm{Q}$. \\
\hline$v$ & H.ulvae density density dependance parameter $\left(\mathrm{m}^{2}\right)$ \\
\hline $\max M\left(U^{*}, 0\right)$ & $\begin{array}{l}\text { Asymptotic concentration or mass of eroded } \mathrm{M} \text { when } \mathrm{u}^{*} \rightarrow \infty\left(=\mathrm{U}^{*}\right) \text { and for zero H.ulvae density } \\
(\mathrm{n}=0)\left(\mathrm{g} \cdot \mathrm{m}^{-2}\right) \text {. }\end{array}$ \\
\hline $\max M\left(U^{*}, \mathbf{N}\right)$ & $\begin{array}{l}\text { Asymptotic concentration or mass of eroded sediment }\left(\mathrm{g} \cdot \mathrm{m}^{-2}\right) \text { when } \mathrm{u}^{*} \rightarrow \infty\left(=\mathrm{U}^{*}\right) \text { and for } \\
\text { H.ulvae density } \mathrm{n} \rightarrow \infty(=\mathrm{N}) \text {. }\end{array}$ \\
\hline $\mathbf{k}$ & Instantaneous erosion rate parameter $\left(\mathrm{s}^{-1}\right)$ \\
\hline$\gamma$ & $\begin{array}{l}\text { Exponential parameter describing dependence of the sigmoid maximum value } \operatorname{maxM}\left(\mathrm{U}^{*}, \mathrm{n}\right) \text { to } \\
\text { the moisture content at the sediment/water interface (no unit). }\end{array}$ \\
\hline
\end{tabular}


Table 3 :

\begin{tabular}{|c|c|c|}
\hline Parameter & Average value (Runnel) & Average value (Ridge) \\
\hline \multicolumn{3}{|c|}{ “2×6 parameter model” for both independent “Runnel/Ridge” models (identical to Willows’ model). } \\
\hline$\alpha$ & $1.28 \pm 0.18$ & $1.56 \pm 0.014$ \\
\hline$\beta\left(\mathrm{m} . \mathrm{s}^{-1}\right)$ & $4.45 \pm 1.04$ & $2.12 \pm 0.01$ \\
\hline$k\left(\min ^{-1}\right)$ & $0.56 \pm 0.13$ & $0.26 \pm 0.01$ \\
\hline $\max M\left(U^{*}, O\right)\left(\mathrm{g} \cdot \mathrm{m}^{-2}\right)$ & $15.80 \pm 4.31$ & $0.97 \pm 0.04$ \\
\hline $\max M\left(U^{*}, N\right)\left(\mathrm{g} \cdot \mathrm{m}^{-2}\right)$ & $59.99 \pm 7.45$ & $6.13 \pm 0.03$ \\
\hline$v\left(\mathrm{~m}^{2}\right.$ per Hydrobia $)$ & $0.08 \times 10^{-4} \pm 0.01 .10^{-4}$ & $1.00 \times 10^{-4} \pm 0.01 .10^{-4}$ \\
\hline \multicolumn{3}{|c|}{ Single "8-parameter model” model including “Moisture content" factor. } \\
\hline$\alpha$ & 1.2 & .52 \\
\hline$\beta\left(\mathrm{m} . \mathrm{s}^{-1}\right)$ & 3.8 & .57 \\
\hline$k\left(\min ^{-1}\right)$ & 0.2 & .08 \\
\hline $\max M\left(U^{*}, O\right)\left(\mathrm{g} \cdot \mathrm{m}^{-2}\right)$ & $15.96 \pm 2.19$ & $0.97 \pm 0.30$ \\
\hline $\max M\left(U^{*}, N\right)\left(\mathrm{g} \cdot \mathrm{m}^{-2}\right)$ & 75.0 & .10 \\
\hline$v\left(\mathrm{~m}^{2}\right.$ per Hydrobia $)$ & $2.40 \times 10$ & $.22 \times 10^{-8}$ \\
\hline$\gamma$ & $0.29 \times 10$ & $.01 \times 10^{-1}$ \\
\hline \multicolumn{3}{|c|}{ Single "9-parameter model" including "Moisture content" factor and with differentiation of $\beta$ for both } \\
\hline$\dot{\alpha}$ & 1.3 & .05 \\
\hline$\beta\left(\mathrm{m} . \mathrm{s}^{-1}\right)$ & $4.41 \pm 0.78$ & $2.12 \pm 0.61$ \\
\hline$k\left(\min ^{-1}\right)$ & & \\
\hline $\max M\left(U^{*}, O\right)\left(\mathrm{g} \cdot \mathrm{m}^{-2}\right)$ & $15.96 \pm 2.19$ & $0.97 \pm 0.32$ \\
\hline $\max M\left(U^{*}, N\right)\left(\mathrm{g} \cdot \mathrm{m}^{-2}\right)$ & 75.0 & 7.70 \\
\hline$v\left(\mathrm{~m}^{2}\right.$ per Hydrobia $)$ & $2.40 \times 10$ & $.22 \times 10^{-8}$ \\
\hline$\gamma$ & $0.29 \times 10$ & $.01 \times 10^{-1}$ \\
\hline Model & Coefficient of determination $\mathbf{r}^{2}$ (runnel) & Coefficient of determination $\mathbf{r}^{2}$ (ridge) \\
\hline \multirow[t]{2}{*}{ “2×6 parameter model” } & $\max M\left(U^{*}, n\right): r^{2}=0.744$ & $\max M\left(U^{*}, n\right): r^{2}=0.869$ \\
\hline & $M: r^{2}=0.883$ & $M: r^{2}=0.904$ \\
\hline \multirow[t]{2}{*}{ "8-parameter model" } & $\max M\left(U^{*}, n\right): r^{2}=0.867$ & $\max M\left(U^{*}, n\right): r^{2}=0.827$ \\
\hline & $M: r^{2}=0.896$ & $M: r^{2}=0.344$ \\
\hline \multirow[t]{2}{*}{ “9-parameter model” } & $\max M\left(U^{*}, n\right): r^{2}=0.867$ & $\max M\left(U^{*}, n\right): r^{2}=0.827$ \\
\hline & $M: r^{2}=0.912$ & $M: r^{2}=0.830$ \\
\hline
\end{tabular}


